\title{
Microbial response to enhanced phosphorus cycling in the North Pacific Subtropical Gyre
}

\author{
Solange Duhamel ${ }^{1,2, *}$, Karin M. Björkman ${ }^{1}$, Joseph K. Doggett ${ }^{1}$, David M. Karl ${ }^{1}$ \\ ${ }^{1}$ Daniel K. Inouye Center for Microbial Oceanography: Research and Education (C-MORE), University of Hawaii, \\ C-MORE Hale, 1950 East West Road, Honolulu, Hawaii 96822, USA
}

${ }^{2}$ Present address: Lamont-Doherty Earth Observatory, Division of Biology and Paleo Environment, Columbia University, PO Box 1000, 61 Route 9W, Palisades, New York 10964, USA

\begin{abstract}
Microbial community response to nitrogen $(\mathrm{N})$ amendments and induced phosphorus (P) stress was investigated in the North Pacific Subtropical Gyre (NPSG). Samples amended with reduced sources of $\mathrm{N}$, in the form of nitrate plus ammonium, showed significant increases in microbial cell abundance and biomass and decreases in dissolved inorganic phosphate (Pi) and silicate concentrations during an incubation period of $6 \mathrm{~d}$. Primary productivity, P uptake rates (as both Pi and adenosine-5'-triphosphate [ATP]) and alkaline phosphatase activity (APA) all increased following $\mathrm{N}$ amendment. Dissolved organic P (DOP) concentrations did not change, but the large increase in APA and ATP uptake rates suggests that DOP was a dynamic pool and an important source for microbial P nutrition in P-stressed samples. Significant changes were also observed in the structure of the microbial community, with Synechococcus and picoalgae abundances increasing substantially in the $\mathrm{N}$-amended treatments, while non-pigmented picoplankton abundances were unchanged. Data on P resource partitioning among groups of picoplankton separated by size using membrane filters of different porosities, or by scattering and fluorescence properties using flow cytometry sorting, indicate that Synechococcus could have a greater role in the NPSG P cycling following episodic N inputs. This experimental manipulation of nutrient loading combined with observations at the total population to the microbial group levels constitutes a unique approach to improve our understanding of microbial community structure and function in response to environmental forcing.
\end{abstract}

KEY WORDS: Phosphorus dynamics - Microbes · Flow cytometry cell sorting · North Pacific Subtropical Gyre

Resale or republication not permitted without written consent of the publisher

\section{INTRODUCTION}

Phosphorus $(\mathrm{P})$ is an essential element for life and has a key role in ocean productivity (Dyhrman et al. 2007, Karl 2007). The concept that nitrogen (N) is the main limiting nutrient in the ocean while $\mathrm{P}$ is limiting in freshwater systems has prevailed in aquatic studies (Howarth 1988). Nevertheless, recent findings have demonstrated that $\mathrm{P}$ limitation may be equally strong across marine and freshwater systems (Elser et al. 2007). In theory, the ultimate limiting nutrient in aquatic ecosystems should be $\mathrm{P}$ because dinitrogen
$\left(\mathrm{N}_{2}\right)$ fixation can relieve $\mathrm{N}$ limitation, while $\mathrm{P}$ is a non-renewable limiting nutrient (Redfield 1934, Tyrrell 1999). Consequently, it is believed that the open ocean, far from continental inputs of nutrients, should evolve towards P-limited conditions. The rise in $\mathrm{N}_{2}$ fixation and the simultaneous disappearance of P stocks observed at Station (Stn) ALOHA between 1989 and 2004 is an illustration of this phenomenon (Karl et al. 1997, 2001, Karl 2007). Nevertheless, because $\mathrm{N}_{2}$ fixation can be limited by iron availability, $\mathrm{N}$ could limit primary productivity on geological timescales (Falkowski 1997). Therefore, an evalua- 
tion of microbial response to changes in nutrient availability is required to predict future ocean states (Karl \& Letelier 2008, Treseder et al. 2011). One experimental approach to study these processes is through nutrient manipulation of natural microbial assemblages.

The most bioavailable form of $\mathrm{P}$ is dissolved inorganic $\mathrm{P}$ as orthophosphate $(\mathrm{Pi})$, but many compounds of the dissolved organic P (DOP) pool can be used as a P source, even under P-sufficient microbial growth (Orrett \& Karl 1987, Björkman \& Karl 1994, Siuda \& Chróst 2001, Nausch \& Nausch 2007, Duhamel et al. 2011). Because DOP concentrations often exceed Pi concentrations in oligotrophic surface seawaters, this pool is increasingly recognized as being important in sustaining microbial growth by providing an alternative P source (Orrett \& Karl 1987, Karl \& Björkman 2002, Nausch \& Nausch 2007, Lomas et al. 2010, Duhamel et al. 2011). Despite the role of DOP in microbe nutrition, relatively little is known about the chemical composition and biological availability of DOP. One way of looking at this problem in $\mathrm{N}$-controlled environments such as the North Pacific Subtropical Gyre (NPSG) is to force the system towards Pi stress by adding fixed $\mathrm{N}$ and following DOP disappearance as well as uptake of selected DOP substrates.

Alkaline phosphatase (AP) is one of several DOPhydrolyzing enzymes, with specificity for a broad spectrum of DOP substrates (e.g. phosphomonoesters). Duhamel et al. (2010) showed that when supplying fixed $\mathrm{N}$ to samples collected from the NPSG, the AP activity (APA) cell ${ }^{-1}$ increased significantly. This suggests that when the microbial assemblage shifts from an N-stressed to a P-stressed status, APA is upregulated. Additionally, using a single-cell approach (enzyme-labeled fluorescence [ELF]), those authors showed that the organisms responsible for the APA were mainly Synechococcus, while less than $5 \%$ of the Prochlorococcus and non-pigmented picoplankton (hereafter referred to as bacteria) were ELF labeled. An important question from these results is how Prochlorococcus and bacteria fulfill their $\mathrm{P}$ needs when the $\mathrm{N}: \mathrm{P}$ ratio is high in dissolved inorganic pools and $\mathrm{P}$ is scarce, as they do not seem to rely on APA to access the AP-hydrolysable fraction of the DOP.

Our objectives were to test microbial community responses to $\mathrm{N}$ amendments and increasing $\mathrm{P}$ stress and to characterize changes in $\mathrm{P}$ partitioning among groups of microbes separated by size fractionation and flow cytometry. We also evaluated DOP utilization as a $\mathrm{P}$ source for microbial nutrition. In this man- uscript, we use the term P stress to indicate a physiological response to $\mathrm{P}$ supply but not necessarily a limitation in growth and biomass (e.g. Dyhrman \& Ruttenberg 2006, Løvdal et al. 2007). Indeed, under low $\mathrm{P}$ conditions, some microorganisms may respond to $\mathrm{P}$ deficiency by upregulating $\mathrm{P}$-scavenging proteins and/or enzymes (e.g. high-affinity Pi-uptake proteins or AP) to facilitate the acquisition of $\mathrm{Pi}$ at low concentration or from DOP, or by using non-P lipids, and can recover from $\mathrm{P}$ stress; while others will be $\mathrm{P}$ limited and show reduced growth rates (Orchard et al. 2003, Dyhrman \& Haley 2006, Tanaka et al. 2006, Dyhrman et al. 2007, Van Mooy et al. 2009).

\section{MATERIALS AND METHODS}

\section{Experimental design}

Seawater was collected at $25 \mathrm{~m}$ at Stn ALOHA $\left(22^{\circ} 45^{\prime} \mathrm{N}, 158^{\circ} 00^{\prime \prime} \mathrm{W}\right)$ in the NPSG during the KM1013 cruise in July 2010. The seawater was prescreened through $202 \mu \mathrm{m}$ Nitex ${ }^{\circledR}$ mesh to remove large zooplankton and placed into acid-cleaned $(10 \% \mathrm{HCl}) 41$ polycarbonate $(\mathrm{PC})$ bottles rinsed 3 times with sample water prior to the start of the experiment. Our goal was to increase the total dissolved $\mathrm{N}$ (TDN):total dissolved $\mathrm{P}$ (TDP) ratios to approximately $32: 1$ and $50: 1$ to induce $\mathrm{P}$ stress. Twelve replicate bottles were prepared for each treatment, corresponding to (1) control (Ctrl, no amendment); (2) NP32, which received $3 \mu \mathrm{mol} \mathrm{l}^{-1}$ dissolved inorganic $\mathrm{N}$ as equimolar additions of sodium nitrate $\left(\mathrm{NaNO}_{3}\right)$ plus ammonium chloride $\left(\mathrm{NH}_{4} \mathrm{Cl}\right)$; and (3) NP50, which received $8 \mu \mathrm{mol} \mathrm{l}^{-1}$ dissolved inorganic $\mathrm{N}$ as equimolar additions of $\mathrm{NaNO}_{3}$ and $\mathrm{NH}_{4} \mathrm{Cl}$. These amendments and corresponding N:P ratios were based on the total dissolved pools typically measured at the Hawaii Ocean Time-series (HOT) Stn ALOHA in July (TDN $\sim 6 \mu \mathrm{mol} 1^{-1}$, TDP $\sim 250 \mathrm{nmol} \mathrm{l}^{-1}$, TDN:TDP ratio $\sim 21$; Karl et al. 2001). All treatments (Ctrl, NP32 and NP50) were incubated in on-deck blue-shielded Plexiglas (Arkema 2069, $1 / 4$ inch thickness, $50 \%$ transmitted light) incubators cooled with surface seawater and sampled at the start of the experiment (T0) and after 48, 96 and $144 \mathrm{~h}$ of incubation. At each time point, triplicate randomized bottles of each treatment were sacrificed to avoid perturbation and possible contamination by resampling. Each bottle was sampled for the following: nutrients as $\mathrm{Pi}$, TDP, DOP (calculated as TDP - Pi), nitrate $\left(\mathrm{NO}_{3}{ }^{-}\right)$, ammonium $\left(\mathrm{NH}_{4}{ }^{+}\right)$, and silicate $(\mathrm{Si})$; biomass as particulate P (partP), chlorophyll a (chl a), 
adenosine-5'-triphosphate (ATP), and cell abundance; and activity and rate measurements as APA, primary productivity (i.e. ${ }^{14} \mathrm{C}$-sodium bicarbonate uptake, hereafter referred to as $\left.{ }^{14} \mathrm{C}-\mathrm{PP}\right), \mathrm{Pi}$, and ATP uptake.

\section{Analytical measurements}

Samples for nutrient determinations were placed into high-density polyethylene (HDPE) bottles and stored frozen for later analysis. $\mathrm{NO}_{3}{ }^{-}, \mathrm{Si}$ and partP concentrations were measured according to the HOT core measurements protocol (http://hahana.soest. hawaii.edu/hot/methods/results.html). For partP analyses, $500 \mathrm{ml}$ samples were filtered through combusted glass fiber filters (Whatman GF/F, $25 \mathrm{~mm}$ ). The filters were stored frozen until analysis, and the filtrates were used for Pi and TDP analysis. Pi concentrations were determined by the magnesiuminduced co-precipitation (MAGIC) method (Karl \& Tien 1992). TDP was measured using wet persulfate oxidation (Menzel \& Corwin 1965) followed by MAGIC. $\mathrm{NH}_{4}{ }^{+}$analysis was based on the formation of an indophenol blue compound that is measured spectrophotometrically at $630 \mathrm{~nm}$ (Hansen \& Koroleff 2007), and a long-pathlength cell was used for increased sensitivity.

For fluorometric chl a determinations, triplicate $200 \mathrm{ml}$ samples were filtered onto GF/F filters $(25 \mathrm{~mm})$ and extracted in $100 \%$ acetone for $>7 \mathrm{~d}$ in the dark at $-20^{\circ} \mathrm{C}$ and then measured before and after acidification using a Turner model AU-10 fluorometer. Purified chl a (\#C-6144, Sigma) was used as the primary standard.

For particulate ATP determinations, triplicate $500 \mathrm{ml}$ samples were filtered onto GF/F filters and immediately extracted in $5 \mathrm{ml}$ boiling Tris buffer (20 mmol l-1, pH 7.4). These samples were stored frozen for subsequent laboratory analysis by the firefly bioluminescence peak height method (Karl \& Holm-Hansen 1978).

Samples for picoplankton enumeration were fixed in a final concentration of $0.2 \%$ paraformaldehyde, flash frozen in liquid $\mathrm{N}$ and stored at $-80^{\circ} \mathrm{C}$. Microbial cell abundances were determined using an Influx Mariner flow cytometer as described in Duhamel et al. (2012). Briefly, pigmented groups (Prochlorococcus, Synechococcus and picoalgae) were enumerated in unstained samples by their chlorophyll and forward scatter signatures. The high phycoerythrin signal in Synechococcus was used to distinguish this group from Prochlorococcus and picoalgae. To visualize non-pigmented picoplankton (bacteria), a $1 \mathrm{ml}$ aliquot was stained with SYBR Green I DNA dye (SG, $0.01 \%$ final concentration). Because bacteria and Prochlorococcus groups exhibit overlapping signal characteristics after SG staining, the abundances of bacteria were calculated by subtracting the Prochlorococcus abundance, determined in the unstained aliquot, from the total SG-stained group abundance (Duhamel et al. 2012). Flow cytometry data were analyzed using FlowJo 7 software (Tree Star). An internal standard of $1 \mu \mathrm{m}$ diameter microspheres (Fluoresbrite, Polysciences) was added to each sample.

\section{APA}

APA was measured using fluorogenic phosphatase substrate 4-methylumbelliferyl phosphate (MUF-P; Sigma-Aldrich) as described by Duhamel et al. (2010, 2011). Measurements were made at saturating concentration of the substrate $\left(1 \mu \mathrm{mol} \mathrm{l^{-1 }}\right)$ and are expressed as maximum hydrolysis rates. All samples were incubated in the dark at in situ temperature. At least 4 measurements were obtained within $8 \mathrm{~h}$ to verify the linearity of the assay. A standard curve using 4-methylumbelliferone (Sigma-Aldrich) from 0 to $500 \mathrm{nmol} \mathrm{l}^{-1}$ in $0.2 \mu \mathrm{m}$ filtered and boiled seawater (from the same sampling location) was used to calculate MUF-P hydrolysis rates (APA, $\mathrm{nmol}^{-1} \mathrm{~h}^{-1}$ ). Blanks (i.e. ultrapure water) and killed controls (i.e. sample fixed with $0.2 \%$ paraformaldehyde, final concentration) were run periodically at saturating concentration and indicated no significant autohydrolysis of the substrate. Cell-specific APA (fmol cell $^{-1} \mathrm{~h}^{-1}$ ) corresponds to the ratio of APA to the total picoplankton cell abundance measured by flow cytometry.

\section{${ }^{14} \mathrm{C}-\mathrm{PP}$}

Primary productivity was determined using ${ }^{14} \mathrm{C}$ (sodium bicarbonate, MP Biomedicals, \#17441H, 1.11 to $2.22 \mathrm{GBq} \mathrm{mmol}^{-1}$ ) as a tracer, following a modification of the HOT core measurements protocol (Karl et al. 1996). The modifications were that samples were incubated in $75 \mathrm{ml}$ PC bottles in the on-deck incubators from dawn to dusk and labeled to a higher initial ${ }^{14} \mathrm{C}$ activity of $90 \mathrm{MBq} \mathrm{l}^{-1}$. For dissolved inorganic carbon concentration, we used the value measured on a separate cast but obtained on the same day and depth as the sample used for our incubation experiment (i.e. $2011 \mu \mathrm{mol} \mathrm{l}^{-1}$ ). 


\section{P uptake}

$\mathrm{Pi}$ and ATP-derived $\mathrm{P}$ uptake rates were determined using ${ }^{32} \mathrm{Pi}$ (orthophosphoric acid, carrier free, MP Biomedicals, \#64014L, $267 \mathrm{TBq} \mathrm{mmol}^{-1}$ ) and $\left[\gamma_{-}{ }^{32} \mathrm{P}\right] \mathrm{ATP} \quad\left(>90 \% \quad\left[\gamma^{-32} \mathrm{P}\right] \mathrm{ATP}, \quad \mathrm{MP}\right.$ Biomedicals, \#35020, $259 \mathrm{TBq} \mathrm{mmol}^{-1}$ ) as tracers, respectively, as described in Duhamel et al. (2012). Samples were incubated in $75 \mathrm{ml} \mathrm{PC}$ bottles in the on-deck incubators and were typically labeled to give an initial activity of 1.2 to $3.2 \mathrm{MBq}^{-1}$ for ${ }^{32} \mathrm{Pi}$ (corresponding to a maximum of 12 pmol $\mathrm{Pi}$ added, representing a $<0.02 \%$ enrichment addition to the $72 \mathrm{nmol} \mathrm{l}^{-1}$ of $\mathrm{Pi}$ at ambient concentration) and 0.8 to $3.2 \mathrm{MBq}^{-1}$ for $\left[\gamma_{-}{ }^{32} \mathrm{P}\right] \mathrm{ATP}$ (corresponding to a maximum of $12 \mathrm{pmol}$ ATP added, representing an addition of $\sim 7 \%$ to the ambient ATP pool of $0.2 \mathrm{nmol} \mathrm{l}^{-1}$ previously measured at Stn ALOHA at the same depth; Björkman \& Karl 2001, 2005). Samples were incubated 6 to $9 \mathrm{~h}$ depending on expected turnover time and biomass. To stop the incubation, non-radioactive Pi or ATP (133 $\mu \mathrm{M}$ of $\mathrm{KH}_{2} \mathrm{PO}_{4}$ and ATP, final concentration) was added to prevent further uptake of the labeled substrates (i.e. cold chase). Negative controls received an equivalent spike of nonradioactive substrates $15 \mathrm{~min}$ prior to introduction of the radioactive isotope, to account for non-biological labeling by ${ }^{32} \mathrm{Pi}$ and $\left[\gamma^{32} \mathrm{P}\right]$ ATP. Activity measured in the negative controls was subtracted from the activity in the samples. Taking the entire dataset into account, negative controls represented $2.1 \pm 1.6$ and $1.2 \pm 0.8 \%$ of the activity measured in the corresponding ${ }^{32} \mathrm{Pi}-$ and $\left[\gamma^{32}\right.$ P]ATP-labeled samples, respectively. Samples for total (i.e. $>0.2 \mu \mathrm{m}$ ) and size-fractionated activities were vacuum filtered onto PC membranes $(0.2,0.6$ and $2 \mu \mathrm{m}$ porosity; $25 \mathrm{~mm}$ diameter) at low pressure ( $<0.6$ bar). Filters were rinsed 3 times with $<0.2 \mu \mathrm{m}$ filtered seawater from the same sampling location and then transferred into $6.5 \mathrm{ml}$ HDPE scintillation vials. Then, $4 \mathrm{ml}$ of scintillation cocktail (Ultima Gold LLT, PerkinElmer) was added, and samples were counted on a Packard Tri-Carb ${ }^{\circledR}$ liquid scintillation counter.

To determine group-specific uptake rates, subsamples from the incubations used to determine total and size-fractionated uptake rates were kept in the dark until sorting $(<8 \mathrm{~h})$ on an Influx Mariner flow cytometer as described in Duhamel et al. (2012). Microbial groups were sorted using the same discrimination parameters as for cell counts. Because previous studies have shown that fixing samples prior to sorting may lead to underestimation of group-specific uptake rates (Zubkov et al. 2007, Casey et al. 2009,
Talarmin et al. 2011, Duhamel et al. 2012), sorted samples were cold chased (100 $\mu \mathrm{M}$, Pi or ATP) but not fixed, and samples for sorting of bacteria were stained with SG for at least $30 \mathrm{~min}$ before sorting (Talarmin et al. 2011). Fluorescent microspheres (1 $\mu \mathrm{m}$ diameter, Fluoresbrite, Polysciences) were added to each sample and sorted at the same time as Prochlorococcus, Synechococcus or bacteria groups, into separate vials, to determine radioactivity because of substrate carryover in sorted droplets (Björkman et al. 2012). Then, $4 \mathrm{ml}$ of liquid scintillation cocktail was added, and samples were counted for radioactivity. The background activity (Bq bead ${ }^{-1}$ ) was subtracted from the sample activity $\left(\mathrm{Bq} \mathrm{cell}{ }^{-1}\right)$. On average, 75 to $100 \times 10^{3}$ Prochlorococcus, 5 to $15 \times 10^{3}$ Synechococcus or 100 to $200 \times 10^{3}$ bacteria were sorted. Radioactivity was undetectable in populations sorted from the negative controls (i.e. seawater subjected to cold chasing $15 \mathrm{~min}$ prior to introduction of radioactive isotope) at T0 and was not further considered in the data analysis.

\section{Calculation and statistical analysis}

Results are reported as mean \pm 1 SD. SigmaPlot 12 (Systat Software) was used for the statistical analysis. One-way ANOVA was performed to compare results between the initial sample (T0) and after 48, 96 and $144 \mathrm{~h}$ of incubation, and significance is reported where $\mathrm{p} \leq 0.05$. Pairwise comparisons between treatments and controls were performed using a $t$-test, and significance is reported where $\mathrm{p} \leq 0.05$.

Pi or ATP turnover times (TT, h) and uptake rates $\left(\right.$ nmol $\left.~^{-1} \mathrm{~h}^{-1}\right)$ were calculated as follows: TT $=$ $\left(R_{\mathrm{t}} / R_{\mathrm{f}}\right)$, and Pi or ATP uptake $=(\mathrm{S} / \mathrm{TT})$, respectively, with the radioactivity on the filter or in the sorted population $\left(R_{\mathrm{f}}, \mathrm{Bq} \mathrm{l}^{-1} \mathrm{~h}^{-1}\right)$, the total tracer added $\left(\mathrm{R}_{\mathrm{t}}\right.$ $\left.\mathrm{Bq}^{-1}\right)$ and the Pi or ATP concentration $\left(S, \mathrm{nmol} \mathrm{l}^{-1}\right)$. A dissolved ATP concentration of $0.2 \mathrm{nmol} \mathrm{l}^{-1}$ previously measured at $25 \mathrm{~m}$ at Stn ALOHA during the same season (Björkman \& Karl 2005) was used to calculate ATP uptake rates. ATP uptake rates are based on the terminal $(\gamma-\mathrm{P})$ P group from ATP, implying that the calculated uptake rate might actually be 3 times higher if all 3 Ps are incorporated by the cells.

\section{RESULTS}

There were significant differences between the control and N-amended treatments at T144 in all the 
parameters measured, with the exception of bacteria and Prochlorococcus cell counts and DOP concentration (Table 1). Variability within the controls over time will be discussed only when it is significantly different from the $\mathrm{N}$-amended treatments. Hereafter, comparisons are between the control at T0 (i.e. initial sample) and the N-amended treatments at T144. Unless otherwise specified, when there was no significant difference between NP32 and NP50, these data were pooled and used to calculate the change relative to T0 (Table 1).

\section{Biomass and cell abundance}

Chl a, ATP and partP concentrations increased by factors of $10.0 \pm 2.8,4.3 \pm 1.2$ and $3.3 \pm 1.4$, respectively ( $<<0.05$; Fig. 1, Table 1). Synechococcus and picoalgae abundances increased by factors of $56.4 \pm$ 7.8 and $9.9 \pm 2.8$, respectively ( $p<0.05$; Fig. $2 \mathrm{C}, \mathrm{D})$.
While Synechococcus is usually characterized by a uniform flow cytometric population in samples from the NPSG (Fig. 2E), 2 subpopulations, hereafter termed $\mathrm{S} 1$ and $\mathrm{S} 2$, could be identified at T144 (Fig. 2F,G). S1 was characterized by higher chlorophyll (red) fluorescence and phycoerythrin (orange) fluorescence than $\mathrm{S} 2(2.9 \pm 0.5$ times and $7.6 \pm 1.0$ $[\mathrm{n}=6]$, respectively). While $\mathrm{S} 2$ abundances were $7.4 \pm 2.5(\mathrm{n}=3)$ times higher than S1 in NP32, S1 abundances were $2.3 \pm 1.1(\mathrm{n}=3)$ times higher than S2 in NP50 (Fig. 2F,G). There was no significant difference between the control and $\mathrm{N}$-amended treatments for bacteria and Prochlorococcus cell abundances; nevertheless, their abundances varied significantly over incubation time. Bacteria abundance increased between the initial sample and T48 but only by a factor of $1.6 \pm 0.1$ and then remained constant until T144. Prochlorococcus abundances decreased between T0 and T144 by a factor of $19.6 \pm 13.5$.

Table 1. Statistical differences between the initial sample (control at T0) and T144 (after $144 \mathrm{~h}$ ) for various parameters between the control and nitrogen (N)-amended treatments (Ctrl vs. NP) and between the N-amended treatments (NP32 vs. NP50). Y denotes statistical difference, and $N$ denotes no statistical difference ( $t$-test, $\mathrm{p} \leq 0.05)$. The factor of increase $(\boldsymbol{\lambda})$ or decrease (ע) relative to T0 is also presented. When there was no difference between NP32 and NP50 treatments, the data were pooled to calculate the change relative to T0. When there was a difference, the result is given for each treatment. Concentrations and rates measured in the initial sample (control at T0) are also given. Data are means \pm SD for triplicate treatments. APA: alkaline phosphatase activity; ATP: adenosine-5'-triphosphate; chl $a$ : chlorophyll $a_{i}{ }^{14} \mathrm{C}$-PP: primary productivity measured as ${ }^{14} \mathrm{C}$ sodium bicarbonate uptake; DOP: dissolved organic phosphorus; $\mathrm{NH}_{4}{ }^{+}$: ammonium; $\mathrm{NO}_{3}{ }^{-}$: nitrate; partP: particulate phosphorus; Pi: dissolved inorganic phosphorus

\begin{tabular}{|c|c|c|c|c|}
\hline \multirow[t]{2}{*}{ Parameter } & \multirow{2}{*}{ T0 } & \multicolumn{3}{|c|}{ Statistical differences at T144 } \\
\hline & & $\begin{array}{c}\text { Ctrl vs. } \\
\text { NP }\end{array}$ & $\begin{array}{c}\text { NP32 vs. } \\
\text { NP50 }\end{array}$ & Change relative to T0 \\
\hline $\operatorname{chl} a\left(\mu g l^{-1}\right)$ & $0.132 \pm 0.017$ & $\mathrm{Y}$ & $\mathrm{N}$ & $\boldsymbol{\nearrow} \times 10 \pm 3$ \\
\hline $\operatorname{ATP}\left(\mathrm{ng} \mathrm{l}^{-1}\right)$ & $42 \pm 2$ & $\mathrm{Y}$ & $\mathrm{N}$ & $\nearrow \times 3.3 \pm 1.4$ \\
\hline partP $\left(\mathrm{nmol} \mathrm{l}^{-1}\right)$ & $23.5 \pm 7$ & $\mathrm{Y}$ & $\mathrm{N}$ & $\boldsymbol{\nearrow} \times 5.1 \pm 1.2$ \\
\hline Bacteria $\left(\times 10^{5}\right.$ cells ml $\left.{ }^{-1}\right)$ & $3.97 \pm 0.05$ & $\mathrm{~N}$ & $\mathrm{~N}$ & $\lambda \times 1.6 \pm 0.1$ \\
\hline Prochlorococcus $\left(\times 10^{5}\right.$ cells ml $\left.{ }^{-1}\right)$ & $2.05 \pm 0.02$ & $\mathrm{~N}$ & $\mathrm{~N}$ & $\searrow \times 20 \pm 13.5$ \\
\hline Synechococcus $\left(\times 10^{2}\right.$ cells ml $\left.{ }^{-1}\right)$ & $7.06 \pm 0.20$ & $\mathrm{Y}$ & $\mathrm{N}$ & $\nearrow \times 56 \pm 8$ \\
\hline Picoalgae $\left(\times 10^{2}\right.$ cells ml $\left.\mathrm{m}^{-1}\right)$ & $5.87 \pm 0.20$ & $\mathrm{Y}$ & $\mathrm{N}$ & $\nearrow \times 9.9 \pm 2.8$ \\
\hline $\mathrm{Pi}\left(\mathrm{nmol} \mathrm{l}^{-1}\right)$ & $72 \pm 3$ & $\mathrm{Y}$ & $\mathrm{N}$ & $\searrow \times 2.3 \pm 0.4$ \\
\hline $\mathrm{NO}_{3}^{-}\left(\mathrm{nmol} \mathrm{l}^{-1}\right)$ & $6.2 \pm 2.0^{\mathrm{a}}$ & $\mathrm{Y}$ & $\mathrm{Y}$ & $\searrow \times 2.9 \pm 0.2(\mathrm{NP} 32), \times 1.1 \pm 0.01(\mathrm{NP} 50)$ \\
\hline $\mathrm{NH}_{4}^{+}\left(\mathrm{nmol} \mathrm{l}^{-1}\right)$ & $25 \pm 11^{\mathrm{a}}$ & $\mathrm{Y}$ & $\mathrm{Y}$ & $\searrow \times 14 \pm 4(\mathrm{NP} 32), \times 16 \pm 8(\mathrm{NP} 50)$ \\
\hline DOP $\left(\mathrm{nmol} \mathrm{l}^{-1}\right)$ & $142 \pm 26$ & $\mathrm{~N}$ & $\mathrm{~N}$ & $\rightarrow$ \\
\hline APA $\left(\mathrm{nmol} \mathrm{l}^{-1} \mathrm{~h}^{-1}\right)$ & $0.16 \pm 0.04$ & $\mathrm{Y}$ & $\mathrm{Y}$ & $\boldsymbol{\nearrow} \times 194 \pm 81(\mathrm{NP} 32), \times 531 \pm 139(\mathrm{NP} 50)$ \\
\hline${ }^{14} \mathrm{C}-\mathrm{PP}$ (total, $\mu g \mathrm{l}^{-1} \mathrm{~d}^{-1}$ ) & $4.51 \pm 0.07$ & $\mathrm{Y}$ & $\mathrm{Y}$ & $\boldsymbol{\nearrow} \times 12 \pm 3(\mathrm{NP} 32), \times 19 \pm 1(\mathrm{NP} 50)$ \\
\hline Pi uptake (total, $\mathrm{nmol}^{-1} \mathrm{~h}^{-1}$ ) & $0.20 \pm 0.0 .1$ & $\mathrm{Y}$ & $\mathrm{N}$ & $\nearrow \times 38 \pm 6$ \\
\hline Pi uptake $\left(0.2-0.6 \mu \mathrm{m}, \mathrm{nmol} \mathrm{l}^{-1} \mathrm{~h}^{-1}\right)$ & $0.09 \pm 0.01$ & $\mathrm{Y}$ & $\mathrm{N}$ & $\nearrow \times 37 \pm 7$ \\
\hline Pi uptake $\left(0.6-2 \mu \mathrm{m}, \mathrm{nmol} \mathrm{l}^{-1} \mathrm{~h}^{-1}\right)$ & $0.08 \pm 0.01$ & $\mathrm{Y}$ & $\mathrm{N}$ & $\boldsymbol{\nearrow} \times 13 \pm 5.5$ \\
\hline Pi uptake $\left(>2 \mu \mathrm{m}, \mathrm{nmol} \mathrm{l}^{-1} \mathrm{~h}^{-1}\right)$ & $0.03^{\mathrm{b}}$ & $\mathrm{Y}$ & $\mathrm{N}$ & $\boldsymbol{\nearrow} \times 107 \pm 49$ \\
\hline ATP uptake (total, pmol $\mathrm{l}^{-1} \mathrm{~h}^{-1}$ ) & $1.76 \pm 0.09$ & $\mathrm{Y}$ & $\mathrm{N}$ & $\boldsymbol{\nearrow} \times 17 \pm 1.5$ \\
\hline ATP uptake $\left(0.2-0.6 \mu \mathrm{m}, \mathrm{pmol} \mathrm{l}^{-1} \mathrm{~h}^{-1}\right)$ & $1.56 \pm 0.09$ & $\mathrm{Y}$ & $\mathrm{N}$ & $\boldsymbol{\nearrow} \times 10 \pm 2(\mathrm{NP} 32), \times 6 \pm 2(\mathrm{NP} 50)$ \\
\hline ATP uptake $\left(0.6-2 \mu \mathrm{m}, \mathrm{pmol} \mathrm{l}^{-1} \mathrm{~h}^{-1}\right)$ & $0.16 \pm 0.03$ & $\mathrm{Y}$ & $\mathrm{Y}$ & $\nearrow \times 53 \pm 13$ \\
\hline ATP uptake $\left(>2 \mu \mathrm{m}, \mathrm{pmol} \mathrm{l}^{-1} \mathrm{~h}^{-1}\right)$ & $0.05 \pm 0.02$ & $\mathrm{Y}$ & $\mathrm{N}$ & $\boldsymbol{\nearrow} \times 202 \pm 110$ \\
\hline
\end{tabular}



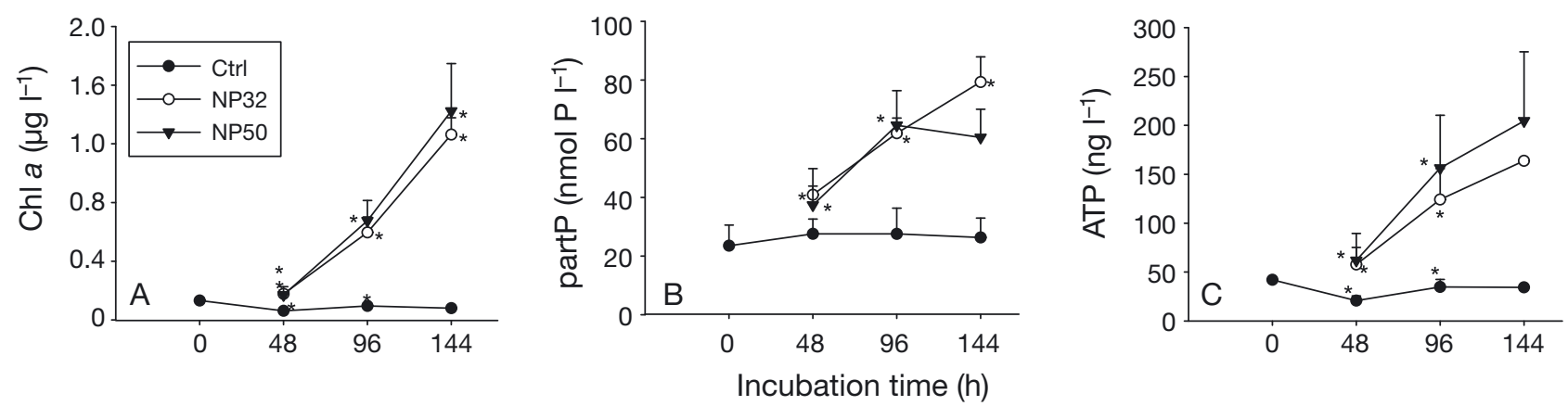

Fig. 1. Variations in (A) chlorophyll a ( $\mathrm{chl} a, \mu \mathrm{g} \mathrm{l^{-1 }}$ ), (B) particulate phosphorus (partP, nmol $\mathrm{P} \mathrm{l}^{-1}$ ) and (C) adenosine-5'triphosphate (ATP, ng $\mathrm{l}^{-1}$ ) concentrations with incubation time ( $x$-axis, h) in the control (Ctrl), NP32 and NP50 treatments. Error bars are SD for triplicate treatments. ${ }^{*}$ Statistical differences from previous time point $(\mathrm{p} \leq 0.05)$
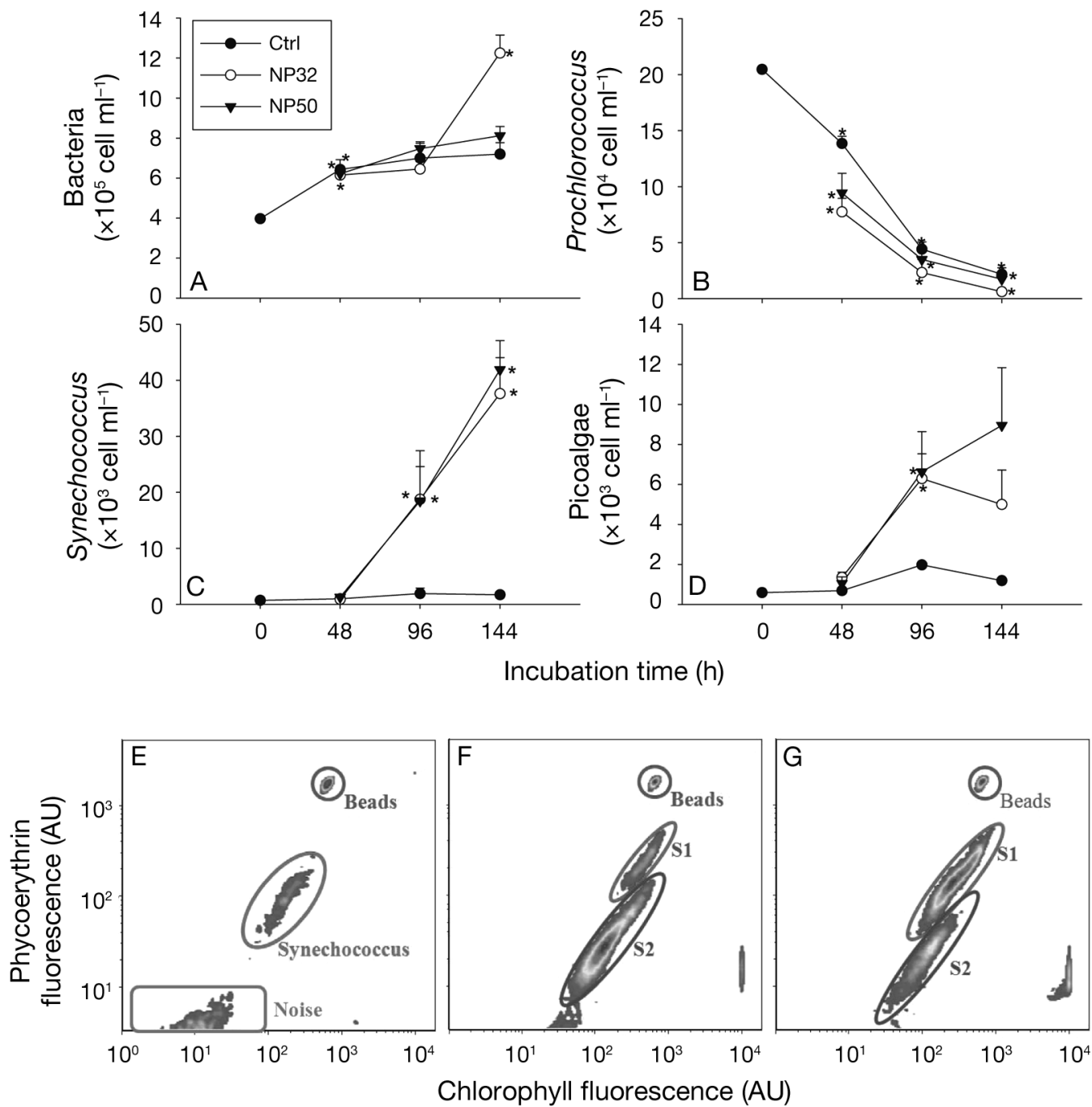

Fig. 2. (A-D) Variations in cell abundances for picoplankton groups enumerated by flow cytometry for (A) bacteria $\left(\times 10^{5}\right.$ cells $\left.\mathrm{ml}^{-1}\right)$, (B) Prochlorococcus $\left(\times 10^{4}\right.$ cell ml $\left.{ }^{-1}\right),\left(\right.$ C) Synechococcus $\left(\times 10^{3}\right.$ cells ml $\left.{ }^{-1}\right)$ and (D) picoalgae $\left(\times 10^{3}\right.$ cells $\left.\mathrm{ml}^{-1}\right)$ with incubation time $\left(x\right.$-axis, h) in the control $(\mathrm{Ctrl})$, NP32 and NP50 treatments. Error bars are SD for triplicate treatments. ${ }^{*}$ Statistical differences from previous time point $(\mathrm{p} \leq 0.05)$. (E-F) Examples of density plots of phycoerythrin $(y$-axis) vs. chlorophyll $(x$-axis) fluorescence (arbitrary units, AU) obtained by flow cytometry at T144 for the (E) control, (F) NP32 and (G) NP50 treatments. The single population of (E) Synechococcus can be compared to the 2 populations of Synechococcus (S1 and S2) identified in the $(\mathrm{F}, \mathrm{G})$ nitrogen-amended treatments. Calibration beads (Beads, $1 \mu \mathrm{m}$ diameter) were used for reference 


\section{Nutrients}

Pi concentration did not vary significantly in the controls $\left(69 \pm 4 \mathrm{nmol} \mathrm{l}^{-1}\right.$, $\mathrm{n}=12$ ). Nevertheless, decreases of $42 \pm 5$ and $36 \pm 6 \mathrm{nmol} \mathrm{l}^{-1}$ were measured in the NP32 and NP50 treatments, respectively $(\mathrm{p}<0.05$; Tables 1 \& 2), with no statistical difference between the treatments. The average decrease in Pi could explain $85 \pm$ $26 \%$ of the partP increases in the $\mathrm{N}$-amended treatments, and a strong correlation was found between these parameters when combining all $\mathrm{Pi}$ and partP data (partP $=-1.04 \times \mathrm{Pi}_{1} \mathrm{r}^{2}=0.84$, Pearson Product Moment Correlation $\mathrm{p}<0.01, \mathrm{n}=36$ ). DOP concentrations did not vary significantly in any treatment, and there was no correlation between DOP and partP concentrations ( $\mathrm{p}>0.01, \mathrm{n}=36$ ). The inorganic N:P ratios $\left(\left[\mathrm{NO}_{3}{ }^{-}+\mathrm{NH}_{4}{ }^{+}\right]: \mathrm{Pi}\right)$ were $0.4 \pm 0.2,37 \pm 2$ and $111 \pm 5$ in the control, NP32 and NP50 treatments, respectively, at T0 and decreased to $0.2 \pm 0.0,21 \pm 1$ and $102 \pm 22$, respectively, at T144.

\section{APA}

APA increased with incubation time in the Namended treatments and was higher than in the control ( $p<0.05$; Fig. 3). Cell-specific APA showed the same general trend as volumetric APA, indicating that variations in APA were not only because of changes in cell abundance. At T144, there was a sig-

Table 2. Initial concentration (T0 control; $\mathrm{nmol} \mathrm{l}^{-1}$ ) and difference in dissolved inorganic phosphorus (Pi), particulate phosphorus (partP), dissolved organic phosphorus (DOP), nitrate $\left(\mathrm{NO}_{3}^{-}\right)$, ammonium $\left(\mathrm{NH}_{4}{ }^{+}\right)$and silicate $(\mathrm{Si})$ concentrations between T0 and T144 in the control and nitrogen (N)-amended treatments (NP32 and NP50). Note that in the $\mathrm{N}$-amended treatments, $\mathrm{NO}_{3}{ }^{-}$and $\mathrm{NH}_{4}{ }^{+}$concentrations at T0 were $1448 \pm 19$ and $1191 \pm 90 \mathrm{nmol} \mathrm{l}^{-1}$ for NP32 and $3937 \pm 65$ and $3848 \pm 57 \mathrm{nmol} \mathrm{l}^{-1}$ for NP50, respectively. (+) and (-) correspond to an increase or a decrease in concentration, respectively. Data are means \pm SD for triplicate treatments

\begin{tabular}{|c|c|c|c|c|}
\hline $\begin{array}{l}\text { Treatment } \\
\left(\mathrm{nmol} \mathrm{l}^{-1}\right)\end{array}$ & T0 & Control & NP32 & NP50 \\
\hline $\mathrm{Pi}$ & $72 \pm 3$ & $(-) 3 \pm 5$ & (-) $42 \pm 5$ & (-) $36 \pm 6$ \\
\hline partP & $23.5 \pm 7$ & (+) $2.8 \pm 8.7$ & (+) $56 \pm 10$ & (+) $37 \pm 10.5$ \\
\hline DOP & $142 \pm 26$ & $(-) 1 \pm 27$ & (+) $22 \pm 27$ & (+) $5 \pm 29$ \\
\hline $\mathrm{NO}_{3}^{-}$ & $6.2 \pm 2.0$ & (-) $3.2 \pm 1.8$ & (-) $942 \pm 38$ & $(-) 246 \pm 58$ \\
\hline $\mathrm{NH}_{4}^{+}$ & $25 \pm 11$ & $(-) 13 \pm 10$ & $(-) 1099 \pm 84$ & (-) $3542 \pm 157$ \\
\hline $\mathrm{Si}$ & $883 \pm 11$ & (-) $153 \pm 57$ & (-) $595 \pm 90$ & $(-) 697 \pm 126$ \\
\hline
\end{tabular}

nificant difference between the $\mathrm{N}$-amended treatments; cell-specific APA was $194 \pm 81$ and was $531 \pm$ 139 times greater than at T0 in the NP32 and NP50 treatments, respectively.

\section{Primary productivity}

Total (i.e. $>0.2 \mu \mathrm{m}){ }^{14} \mathrm{C}$-PP increased by factors of $12 \pm 3$ and $19 \pm 1$ in the NP32 and NP50 treatments, respectively $(p<0.05)$. In the NP32 and NP50 treatments, the ${ }^{14} \mathrm{C}-\mathrm{PP}: \mathrm{chl}$ a ratios increased by factors of $2.6 \pm 0.5\left(90 \pm 16 \mathrm{~d}^{-1}\right)$ and $2.7 \pm 0.3\left(94 \pm 5 \mathrm{~d}^{-1}\right)$, respectively, between T0 and T96 and then decreased by factors of $1.9 \pm 0.3\left(47 \pm 2 \mathrm{~d}^{-1}\right)$ and $1.5 \pm 0.2(63 \pm$ $\left.9 \mathrm{~d}^{-1}\right)$, respectively, between T96 and T144 $(\mathrm{p}<0.05)$. The daily photosynthetically active radiation measured at the same incubation depth (i.e. $25 \mathrm{~m}$ ) did not vary much between incubation days, and thus changes in photosynthetic efficiency were most likely the result of physiological changes or species shifts. ${ }^{14} \mathrm{C}$-PP significantly increased in all size fractions in the $\mathrm{N}$-amended treatments (Fig. $4 \mathrm{D}, \mathrm{E}, \mathrm{F}$ ). At $\mathrm{T} 0,{ }^{14} \mathrm{C}-\mathrm{PP}$ in the $0.2-0.6,0.6-2$ and $>2 \mu \mathrm{m}$ fractions were 1.44 $\pm 0.15,1.91 \pm 0.21$ and $1.16 \pm 0.23 \mu \mathrm{g} \mathrm{C} \mathrm{l}^{-1}$ $\mathrm{d}^{-1}$, respectively. In the NP32 and NP50 treatments, ${ }^{14} \mathrm{C}$-PP increased to maximum values of $3.4 \pm 0.1$ and $4.8 \pm 1.1 \mu \mathrm{g} \mathrm{Cl}^{-1} \mathrm{~d}^{-1}$ in the $0.2-0.6 \mu \mathrm{m}$ fraction, $20 \pm 6$ and $18 \pm$ $4 \mu \mathrm{C} \mathrm{Cl}^{-1} \mathrm{~d}^{-1}$ in the $0.6-2$ fraction and $47 \pm 2$ and $69 \pm 9 \mu \mathrm{g} \mathrm{C} \mathrm{l}^{-1} \mathrm{~d}^{-1}$ in the $>2 \mu \mathrm{m}$ fraction, respectively $(p<0.05)$. At $\mathrm{T} 144$, the relative contribution of the $0.2-0.6 \mu \mathrm{m}$ size fraction to ${ }^{14} \mathrm{C}$-PP was lower than at $\mathrm{T} 0$ in all treatments $(\mathrm{p}<0.05)$, likely because of the large decrease in Prochlorococcus abundance. On the contrary, the contribution of the fraction $>2 \mu \mathrm{m}$ doubled (Fig. 4A,B,C). 

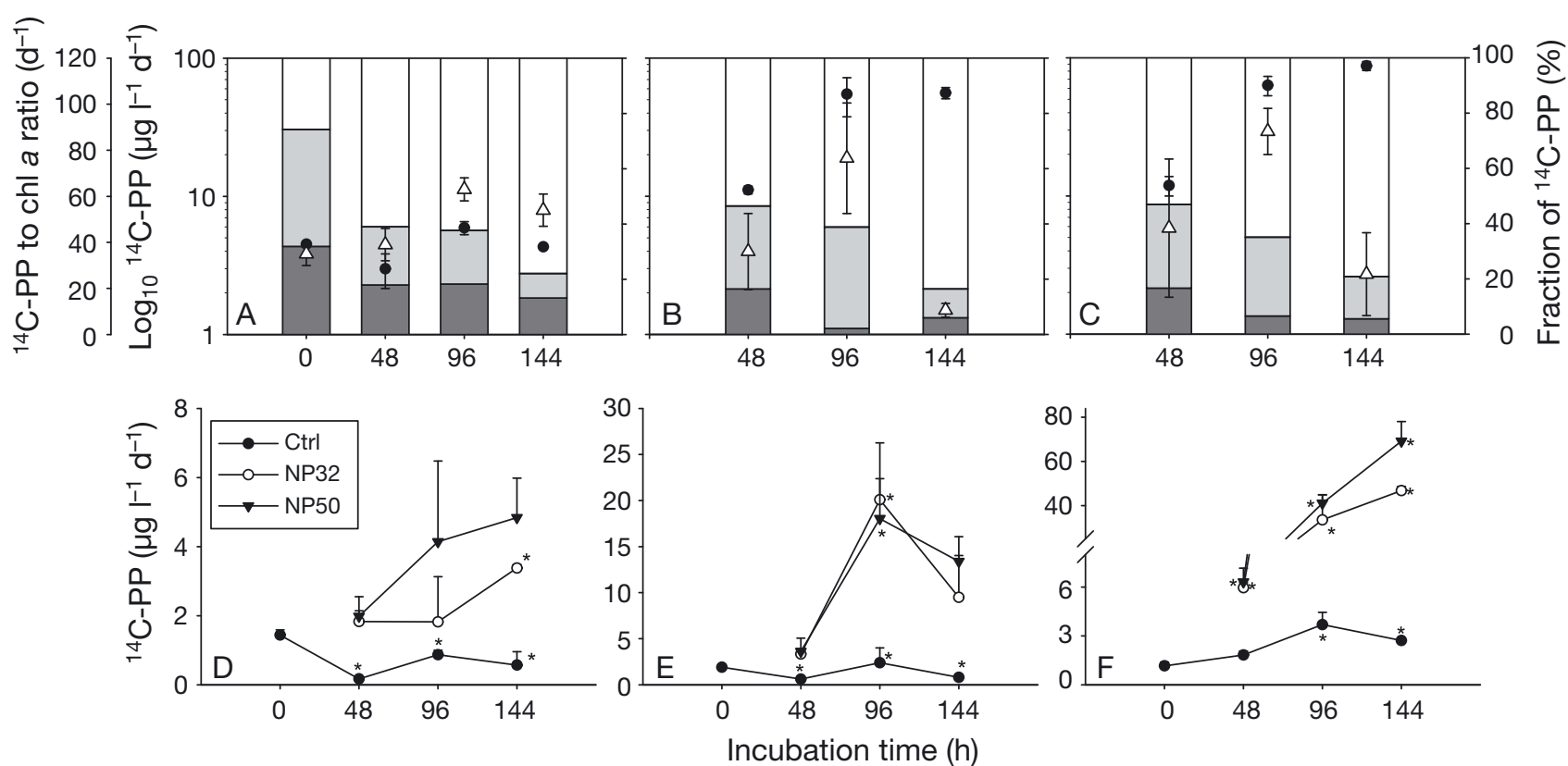

Fig. 4. Variations in primary production measured by ${ }^{14} \mathrm{C}$-sodium bicarbonate uptake $\left({ }^{14} \mathrm{C}\right.$-PP, $\mu \mathrm{g} \mathrm{l}^{-1} \mathrm{~d}^{-1}$, left $y$-axis, $\log { }_{10}$ scale, black dots), ${ }^{14} \mathrm{C}$-PP:chl a ratio $\left(\mathrm{d}^{-1}\right.$, left offset $y$-axis, white triangles) and contribution of the $0.2-0.6$ (dark grey stacked bars), 0.6-2 (light grey stacked bars) and $>2 \mu \mathrm{m}$ (white stacked bars) fractions to total ${ }^{14} \mathrm{C}$-PP (\%, right $y$-axis) with incubation time ( $h, x$-axis) in the (A) control (Ctrl), (B) NP32 and (C) NP50 treatments. Variations in ${ }^{14} \mathrm{C}-\mathrm{PP}\left(\mu \mathrm{g} \mathrm{l} \mathrm{l}^{-1} \mathrm{~d}^{-1}\right)$ by the (D) 0.2-0.6, (E) $0.6-2$ and $(F)>2 \mu \mathrm{m}$ fractions in the control (Ctrl), NP32 and NP50 treatments. Error bars are SD for triplicate treatments. ${ }^{*}$ Statistical differences from previous time point $(\mathrm{p} \leq 0.05)$

\section{Inorganic and organic P uptake}

Pi and ATP uptake increased in all fractions of the $\mathrm{N}$-amended treatments $(\mathrm{p}<0.05)$, but no statistical difference was found between the $2 \mathrm{~N}$-amended treatments, except for the contribution of the 0.2$0.6 \mu \mathrm{m}$ fraction to ATP uptake (Table 1, Fig. 5). In the $\mathrm{N}$-amended treatments, total (i.e. $>0.2 \mu \mathrm{m}) \mathrm{Pi}$ and ATP uptake increased by factors of $38 \pm 6$ and $17 \pm$ 1.5 , respectively $(\mathrm{p}<0.05)$.

Pi uptake in the $0.2-0.6,0.6-2$ and $>2 \mu \mathrm{m}$ fractions increased by factors of $37 \pm 7,13 \pm 5.5$ and $107 \pm 49$, respectively ( $p<0.05$; Table 1 ). The $0.2-0.6,0.6-2$ and $>2 \mu \mathrm{m}$ fractions represented $44 \pm 2.5,41 \pm 2$ and $15 \pm 0.2 \%$, respectively, of the total Pi uptake at T0, while they represented $46 \pm 8,15 \pm 7$ and $39 \pm 12 \%$, respectively, at T144 (Fig. 5). The contribution to $\mathrm{Pi}$ uptake by the $>10 \mu \mathrm{m}$ fraction was measured at T96 and T144 only. Pi uptake rates in the $\mathrm{N}$-amended treatments were higher than in the control $(p<0.05)$. The control and NP32 treatments did not vary significantly between T96 and T144, while NP50 increased with incubation time $(p<0.05)$. Pi uptake by the $>10 \mu \mathrm{m}$ fraction increased with increasing $\mathrm{N}$-amendment: NP50 $\left(0.56 \pm 0.09 \mathrm{nmol} \mathrm{l}^{-1} \mathrm{~h}^{-1}\right)>\mathrm{NP} 32(0.29 \pm$ $\left.0.02 \mathrm{nmol} \mathrm{l}^{-1} \mathrm{~h}^{-1}\right)>$ control $\left(0.01 \pm 0.01 \mathrm{nmol} \mathrm{l}^{-1} \mathrm{~h}^{-1}\right)$ $(\mathrm{p}<0.05)$.
ATP uptake in the $0.2-0.6,0.6-2$ and $>2 \mu \mathrm{m}$ fractions increased by factors of $10 \pm 2$ (NP32) and $6 \pm 2$ (NP50), $53 \pm 13$ (no difference between $\mathrm{N}$-amended treatments) and $202 \pm 110$ (no difference between $\mathrm{N}$-amended treatments), respectively $(\mathrm{p}<0.05$; Table 1). The $0.2-0.6,0.6-2$ and $>2 \mu \mathrm{m}$ fractions represented $88 \pm 1,9 \pm 1$ and $2 \pm 1 \%$ of the total ATP uptake at $\mathrm{T} 0$, respectively, underscoring the dominance of the smaller-sized microbes in ATP uptake. Nevertheless, at T144, the contribution of the 0.2$0.6 \mu \mathrm{m}$ fraction to ATP uptake had greatly decreased to $56 \pm 4$ and $29 \pm 9 \%$ in the NP32 and NP50 treatments, respectively $(\mathrm{p}<0.05)$, while the contributions of the $0.6-2$ and $>2 \mu \mathrm{m}$ fractions to ATP uptake in the $\mathrm{N}$-amended treatments increased to $29 \pm 5.5$ and $29 \pm$ $12 \%$, respectively. The contribution of the $>10 \mu \mathrm{m}$ fraction to ATP uptake was measured at T96 and T144, and although there were differences between treatments $(\mathrm{p}<0.05)$, reaching $1.5 \pm 0.4,6.4 \pm 1.1$, $15.4 \pm 2.8 \%$ at T144 in the control, NP32 and NP50, respectively, within treatments the relative contribution did not change with incubation time.

Pi and ATP uptake by bacteria, Prochlorococcus and Synechococcus populations, as determined by flow cytometry sorting, showed that bacteria and Prochlorococcus were the main contributors to $\mathrm{Pi}$ uptake, while bacteria dominated ATP uptake in the 

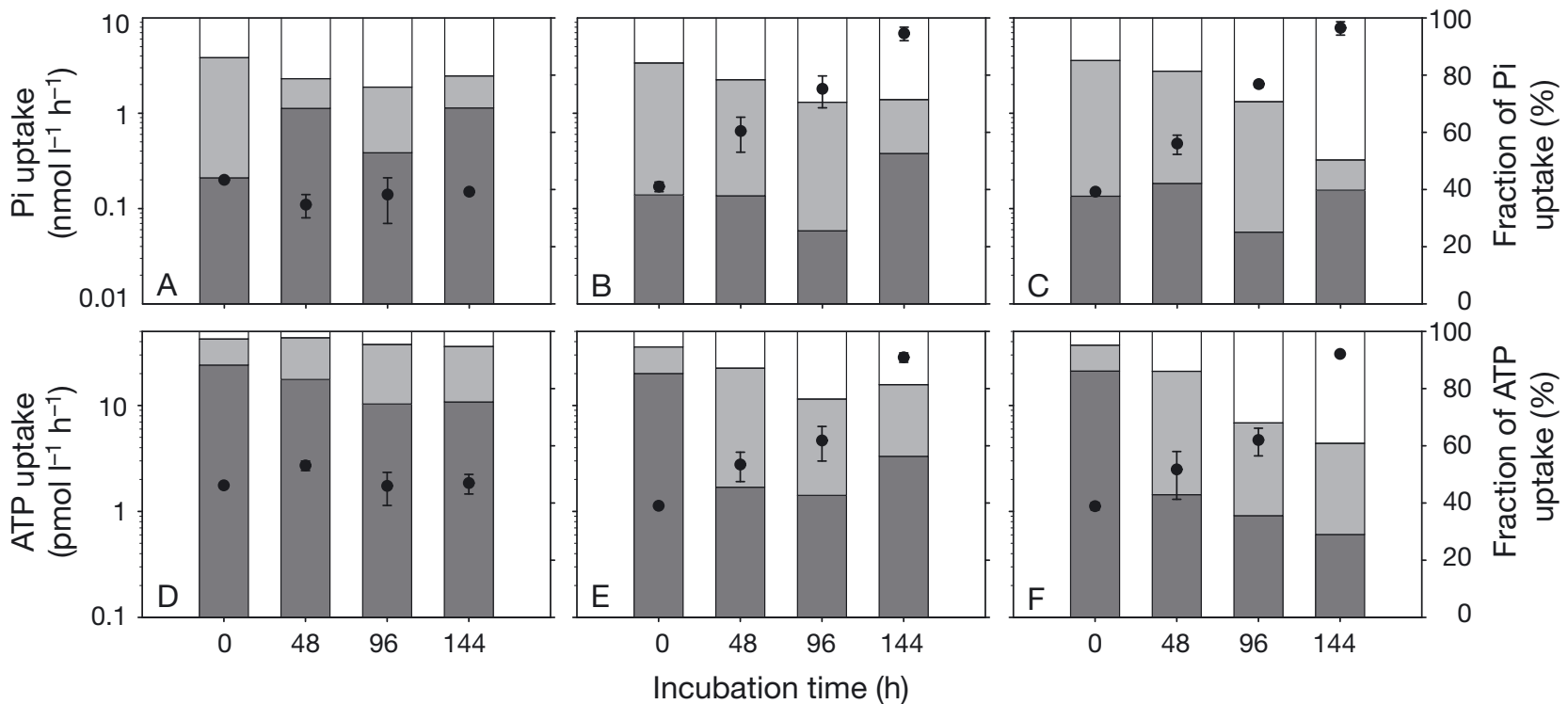

Fig. 5. Variations in $(\mathrm{A}, \mathrm{B}, \mathrm{C})$ dissolved inorganic phosphorus (Pi) (nmol $\mathrm{l}^{-1} \mathrm{~h}^{-1}$, left $y$-axis, $\log _{10}$ scale, black dots) and (D,E,F) ATP uptake (pmol $\mathrm{l}^{-1} \mathrm{~h}^{-1}$, left $y$-axis, $\log _{10}$ scale, black dots) and in the contribution of the 0.2-0.6 (dark grey stacked bars), $0.6-2$ (light grey stacked bars) and $>2 \mu \mathrm{m}$ (white stacked bars) fractions to total Pi and ATP uptake (\%, right $y$-axis) with incubation time ( $h, x$-axis) in the $(A, D)$ control, $(B, E)$ NP32 and $(C, F)$ NP50 treatments. Error bars are SD for triplicate treatments

initial sample at T0. Pi and ATP uptake by these 3 populations increased in the $\mathrm{N}$-amended treatments over time and were much higher than in the controls, except for bacteria ATP uptake, which was lower at T48 and T96 (Table 3). Although the contribution of Prochlorococcus to Pi and ATP uptake was larger in the $\mathrm{N}$-amended treatments than in the controls, it decreased with incubation time because of a decrease in Prochlorococcus cell abundance (Fig. 2). Bacteria dominated both Pi and ATP uptake in all treatments (Table 3). The contribution of Synechococcus populations (total or S1 and S2; Table 3) was measured after $4 \mathrm{~d}$ of incubation in NP50 and after $6 \mathrm{~d}$ of incubation for all treatments. Synechococcus Pi and ATP uptake rates at T144 were in the same order of magnitude as rates by bacteria measured at T96. In the control at T144, $0.04 \%$ of the P taken up by Synechococcus was from ATP, while in the $\mathrm{N}$-amended treatments it increased to 0.1 to $0.3 \%$. In the control at T96, $1.5 \%$ of the P taken up by bacteria was from ATP, while in the $\mathrm{N}$-amended treatments it decreased to 0.2 to $0.4 \%$. The increased Pi uptake by bacteria and Synechococcus in the N-amended treatments was also illustrated in per-cell activity (by bacteria, 0.23 and $1.36 \mathrm{amol} \mathrm{cell}^{-1} \mathrm{~h}^{-1}$ at T96, and by Synechococcus, 0.56 and $7.59 \mathrm{amol} \mathrm{cell}^{-1} \mathrm{~h}^{-1}$ at T144 in the control and NP50 treatments, respectively). While population S2 presented higher rates than S1 in the NP32 treatment, the reverse was true for the
NP50 treatment. For Pi uptake, this was mainly because of higher cell abundances for S2 than S1 in NP32 but higher cell abundances for S1 than S2 in NP50 (Fig. 2), since per-cell activities were higher for S1 in both treatments (S1: 16 and 22 and S2: 10 and $21 \mathrm{amol} \mathrm{cell}^{-1} \mathrm{~h}^{-1}$, in NP32 and NP50, respectively).

\section{DISCUSSION}

Although $\mathrm{N}$ appears to be the limiting nutrient in the NPSG (Van Mooy \& Devol 2008, Duhamel et al. 2010, Mahaffey et al. 2012, this study), Pi concentrations are temporally variable (Karl \& Tien 1997) and can be limiting for at least part of the microbial community (e.g. during or after seasonal phytoplankton blooms; Watkins-Brandt et al. 2011). Furthermore, changes in the average TDN:TDP pool ratio measured at the time-series Stn ALOHA indicate an accumulation of $\mathrm{N}$ relative to $\mathrm{P}$, which can be explained by the growth of $\mathrm{N}_{2}$-fixing microorganisms (Karl et al. 1997). The NPSG has thus been hypothesized to be evolving towards $\mathrm{P}$ limitation because of changes in the plankton community driven by climate variations (Karl et al. 2001). DOP remains in much larger concentration than $\mathrm{Pi}$, but little is known about its availability for P nutrition (Karl \& Björkman 2002, Dyhrman et al. 2007, Nausch \& Nausch 2007). We propose an approach to test the microbial capacity to 
Table 3. Dissolved inorganic phosphorus ( $\mathrm{Pi}_{;}$pmol $\mathrm{l}^{-1} \mathrm{~h}^{-1}$ for flow-sorted populations or nmol $\mathrm{l}^{-1} \mathrm{~h}^{-1}$ for size fraction) and adenosine-5'-triphosphate (ATP; fmol $\mathrm{l}^{-1} \mathrm{~h}^{-1}$ for flow-sorted populations or pmol $\mathrm{l}^{-1} \mathrm{~h}^{-1}$ for size fraction) uptake rates in the control (Ctrl) and nitrogen-amended (NP32 and NP50) treatments for flow-sorted populations of bacteria, Prochlorococcus and Synechococcus and for the $0.2-0.6,0.6-2,>2$ and $>10 \mu \mathrm{m}$ size fractions at T0, T48, T96 and T144 h of incubation. A triplicate control was sorted at T0, and 1 replicate of each treatment was sorted thereafter. Mean \pm SD is for triplicate treatments. S1 and S2 correspond to high and low phycoerythrin fluorescence (i.e. in the orange channel), respectively, in Synechococcus populations. (-) not applicable; ND: not determined

\begin{tabular}{|c|c|c|c|c|c|c|c|c|}
\hline \multirow{2}{*}{$\begin{array}{l}\text { Incubation } \\
\text { time }(\mathrm{h})\end{array}$} & \multicolumn{3}{|c|}{ Pi uptake rates (pmol $\mathrm{l}^{-1} \mathrm{~h}^{-1}$ ) } & \multicolumn{5}{|c|}{ ATP uptake rates $\left(\mathrm{fmol} \mathrm{l}^{-1} \mathrm{~h}^{-1}\right)$} \\
\hline & Ctrl & NP32 & NP50 & Ctrl & & & & \\
\hline \multicolumn{9}{|l|}{ Bacteria } \\
\hline 0 & ND & - & - & ND & & - & & \\
\hline 48 & 31.8 & 438.9 & 193.6 & 2255 & & 56 & & \\
\hline 96 & 159.0 & 677.7 & 1016.9 & 2334 & & 77 & & \\
\hline 144 & ND & $\mathrm{ND}^{\mathrm{a}}$ & $\mathrm{ND}^{\mathrm{a}}$ & 1984 & & & & \\
\hline \multicolumn{9}{|c|}{ Prochlorococcus } \\
\hline 0 & $96.9 \pm 13.6$ & - & - & $26 \pm 5.6$ & & & & \\
\hline 48 & 16.0 & 49.5 & 70.3 & 23.0 & & .7 & & \\
\hline 96 & 3.4 & 1.6 & 36.4 & 2.6 & & 6 & & \\
\hline 144 & 23.5 & $\mathrm{ND}^{\mathrm{a}}$ & $\mathrm{ND}^{\mathrm{a}}$ & 4.9 & & $\mathrm{D}^{\mathrm{a}}$ & & \\
\hline \multicolumn{9}{|c|}{ Synechococcus } \\
\hline 0 & $1.26 \pm 0.98$ & - & - & ND & & - & & \\
\hline 48 & ND & ND & ND & ND & & $\mathrm{D}$ & & \\
\hline \multirow[t]{2}{*}{96} & ND & ND & 0.20 & ND & & $\mathrm{D}$ & & \\
\hline & & $\mathrm{S} 1 \quad \mathrm{~S} 2$ & $\mathrm{~S} 1 \quad \mathrm{~S} 2$ & & S1 & S2 & S1 & S2 \\
\hline 144 & 1.0 & $57.5 \quad 514.3$ & $618.9 \quad 413.1$ & 0.4 & 61.5 & 1711 & 766 & 477 \\
\hline & \multicolumn{3}{|c|}{ Pi uptake rates $\left(\mathrm{nmol} \mathrm{l}^{-1} \mathrm{~h}^{-1}\right)$} & \multicolumn{5}{|c|}{ ATP uptake rates (pmol $\left.\mathrm{l}^{-1} \mathrm{~h}^{-1}\right)$} \\
\hline \multicolumn{9}{|l|}{$0.2-0.6 \mu \mathrm{m}$} \\
\hline 0 & $0.09 \pm 0.01$ & - & - & $1.56 \pm 0.09$ & & & & \\
\hline 48 & $0.07 \pm 0.02$ & $0.24 \pm 0.09$ & $0.20 \pm 0.07$ & $2.25 \pm 0.28$ & 1.26 & $=0.16$ & 1.07 & 0.30 \\
\hline 96 & $0.07 \pm 0.05$ & $0.46 \pm 0.19$ & $0.51 \pm 0.12$ & $1.30 \pm 0.47$ & 1.99 & $=0.52$ & 1.68 & 0.45 \\
\hline 144 & $0.10 \pm 0.01$ & $3.62 \pm 0.77$ & $3.12 \pm 0.10$ & $1.40 \pm 0.32$ & 16.02 & $=2.68$ & 8.88 & 2.68 \\
\hline \multicolumn{9}{|l|}{$0.6-2 \mu \mathrm{m}$} \\
\hline 0 & $0.08 \pm 0.01$ & - & - & $0.16 \pm 0.03$ & & - & & \\
\hline 48 & $0.01 \pm 0.00$ & $0.26 \pm 0.12$ & $0.19 \pm 0.05$ & $0.40 \pm 0.03$ & 1.15 & $=0.43$ & 1.07 & 0.62 \\
\hline 96 & $0.03 \pm 0.03$ & $0.81 \pm 0.38$ & $0.92 \pm 0.16$ & $0.36 \pm 0.10$ & 1.57 & $=0.84$ & 1.53 & 0.69 \\
\hline 144 & $0.02 \pm 0.01$ & $1.29 \pm 0.62$ & $0.83 \pm 0.10$ & $0.36 \pm 0.06$ & 7.13 & $=0.51$ & 9.73 & 1.33 \\
\hline \multicolumn{9}{|l|}{$>2 \mu \mathrm{m}$} \\
\hline 0 & 0.03 & - & - & $0.05 \pm 0.02$ & & & & \\
\hline 48 & $0.02 \pm 0.02$ & $0.14 \pm 0.05$ & $0.09 \pm 0.02$ & $0.06 \pm 0.01$ & 0.36 & $=0.28$ & 0.35 & 0.28 \\
\hline 96 & $0.03 \pm 0.01$ & $0.53 \pm 0.12$ & $0.59 \pm 0.13$ & $0.08 \pm 0.03$ & 1.10 & $=0.41$ & 1.51 & 0.28 \\
\hline 144 & $0.03 \pm 0.01$ & $1.97 \pm 0.12$ & $3.90 \pm 1.26$ & $0.10 \pm 0.02$ & 5.29 & 1.05 & 11.99 & 2.69 \\
\hline \multicolumn{9}{|l|}{$>10 \mu \mathrm{m}$} \\
\hline 0 & ND & - & - & ND & & & & \\
\hline 48 & ND & ND & ND & ND & & & & \\
\hline 96 & $0.01 \pm 0.01$ & $0.25 \pm 0.09$ & $0.20 \pm 0.02$ & $0.03 \pm 0.00$ & 0.23 & $=0.04$ & 0.56 & 0.05 \\
\hline 144 & $0.01 \pm 0.01$ & $0.29 \pm 0.02$ & $0.56 \pm 0.09$ & $0.03 \pm 0.01$ & 1.82 & $=0.35$ & 4.75 & 1.12 \\
\hline
\end{tabular}

respond to short-term change in N:P ratio availability at the community and microbial group-specific level.

\section{Microbial response to short-term change in $\mathrm{N}: \mathrm{P}$ ratio availability}

A previous study conducted at a similar location and time of the year and using $\mathrm{N}$ additions as in the
NP32 treatment assessed the APA regulation capacities of microbial populations in the NPSG (Duhamel et al. 2010). Those authors showed that total APA was enhanced in $\mathrm{N}$-amended samples and reduced in P-amended samples and that Synechococcus was the most abundant microbe with APA at the end of the experiment. These results demonstrated that APA is regulated by $\mathrm{P}$ availability in the NPSG but raised questions on what source of $\mathrm{P}$ other microbial groups 
would depend on, since they did not seem to rely on the APA-hydrolysable fraction of the DOP when the NPSG is P stressed. Since the stocks of Pi and DOP are controlled by biological utilization and production and because most of the DOP must be remineralized before the cells can take it up as $\mathrm{Pi}$, fluxes should provide a better understanding of sources of $\mathrm{P}$ than stocks only.

In the present experiment, we further assessed the microbial response to induced P stress in the NPSG by studying bulk and group-specific Pi and ATP uptake in $2 \mathrm{~N}$-amended treatments with different $\mathrm{N}: \mathrm{P}$ ratios. APA increased after $2 \mathrm{~d}$ of incubation, and rates were highly enhanced between T96 and T144, suggesting that following $\mathrm{N}$ additions, microbial growth was stimulated and Pi concentrations became in short supply, driving the microbial community to use part of the DOP to contribute to cell demand for P. Interestingly, there was no additional increase in the biomass, cell abundance and uptake rate parameters in the NP50 treatment. Only APA was significantly higher in the NP50 treatment at T144, suggesting that the additional $\mathrm{N}$ did not further stimulate growth but stimulated the need for reduced carbon and $\mathrm{P}$ that are made available after hydrolysis of DOP by APA (Pradel \& Boquet 1991, Van Wambeke et al. 2002).

The large increase in APA suggests that microbial communities were P stressed, while the increase in biomass, cell abundance and productivity parameters suggests that microbe growth was not P limited in the $\mathrm{N}$-amended treatments. Half-saturation constants $\left(K_{\mathrm{m}}\right)$ for Prochlorococcus and bacteria $\mathrm{Pi}$ uptake were measured at the same location but in separate experiments from this study (see Björkman et al. 2012). Those authors showed that Prochlorococcus and bacteria had $K_{\mathrm{m}}$ of $18.2 \pm 6.5$ and $23.7 \pm$ $70.1 \mathrm{nmol} \mathrm{l}^{-1}$, respectively, which are lower than the Pi concentrations measured at T0 and T144 in this experiment and suggest that those groups were not Pi limited. Nevertheless, results showed large increases in APA, Pi and ATP uptake rates (including at a per-cell level) as well as large decreases in $\mathrm{Pi}$ turnover time $(15.3 \pm 0.5 \mathrm{~d}$ and $4.4 \pm 0.2 \mathrm{~h}$ in the T0 sample and at $\mathrm{T} 144$, respectively, in the $\mathrm{N}$-amended treatment) in the range of values previously reported in P-deficient environments such as the Sargasso or Mediterranean Seas (Cotner et al. 1997, Zohary \& Robarts 1998, Moutin et al. 2002, Tanaka et al. 2004, 2006, Casey et al. 2009, Sohm \& Capone 2010). Together, these results suggest that microbial populations were $\mathrm{P}$ stressed but not $\mathrm{P}$ limited in the $\mathrm{N}$ amended treatments.

\section{Effect of short-term change in $\mathrm{N}$ and $\mathrm{P}$ availability on $\mathrm{N}$ consumption and $\mathrm{N}: \mathrm{P}$ ratios}

The N:P ratio in the dissolved nutrient pools decreased with incubation time in both $\mathrm{N}$-amended treatments. Decreases in N:P ratios are likely to be because of growth of microorganisms using the added $\mathrm{N}$, causing relaxation of $\mathrm{N}$ limitation. Phytoplankton are thought to prefer $\mathrm{NH}_{4}{ }^{+}$as an $\mathrm{N}$ source, since the energetic costs of $\mathrm{NH}_{4}{ }^{+}$assimilation are lower than that of $\mathrm{NO}_{3}{ }^{-}$(which needs to be reduced to $\mathrm{NH}_{4}{ }^{+}$to be assimilated; e.g. Losada \& Guerrero 1979). The microbial communities used more $\mathrm{NO}_{3}{ }^{-}$in NP32 than in NP50. On average, $46 \%$ of the TDN (here, $\mathrm{TDN}=\mathrm{NH}_{4}{ }^{+}+\mathrm{NO}_{3}{ }^{-}$) used by microorganisms after $6 \mathrm{~d}$ was from $\mathrm{NO}_{3}{ }^{-}$in NP32, while it was only $6.5 \%$ in NP50 (Table 2). This might be the result of differences in microbial diversity between the 2 treatments, with more microbes growing on $\mathrm{NO}_{3}{ }^{-}$in NP32 than in NP50 (Middelburg \& Nieuwenhuize 2000, Zehr \& Ward 2002). Nevertheless, considering that microbial abundances were similar in both treatments at T144 and that $3542 \pm 157 \mathrm{nmol} \mathrm{l}{ }^{-1}$ of $\mathrm{NH}_{4}{ }^{+}$ was used in NP50, while in NP32, $1191 \pm 90 \mathrm{nmol} \mathrm{l}^{-1}$ was available at T0 and $1099 \pm 84 \mathrm{nmol} \mathrm{l}^{-1}$ was used at T144, microbes may have run out of $\mathrm{NH}_{4}{ }^{+}$earlier in NP32 than in NP50, driving them to rely on $\mathrm{NO}_{3}{ }^{-}$. This result might also be because of $\mathrm{NH}_{4}{ }^{+}$inhibition of $\mathrm{NO}_{3}{ }^{-}$uptake. Indeed, previous studies on culture and field samples showed that $\mathrm{NH}_{4}{ }^{+}$might prevent $\mathrm{NO}_{3}{ }^{-}$uptake even at relatively low concentrations (Cochlan \& Harrison 1991, Conway 1977, Dugdale et al. 2006, 2007). Nevertheless, field studies show that the reduction of $\mathrm{NO}_{3}{ }^{-}$uptake in the presence of $\mathrm{NH}_{4}{ }^{+}$ is rarely severe and is a highly variable phenomenon (Dortch 1990). N could also be lost as a gas through denitrification or $\mathrm{N}_{2} \mathrm{O}$ production, whereas there is no equivalent path for $\mathrm{P}$.

\section{Effect of short-term change in $\mathbf{N}$ and $\mathbf{P}$ availability on DOP dynamics}

Despite enhanced DOP utilization suggested by APA and increased ATP uptake rate in the Namended treatments, DOP concentration did not vary among the different treatments. These results emphasize the difficulties in studying DOP utilization and production by measuring changes in concentration alone (Ruttenberg \& Dyhrman 2012). Interestingly, although Pi uptake rates were highly enhanced in the $\mathrm{N}$-amended treatments, there was still measurable $\mathrm{Pi}$ concentration after $6 \mathrm{~d}$ of incubation 
$\left(\mathrm{Pi}=30 \pm 5\right.$ and $36 \pm 6 \mathrm{nmol} \mathrm{l}^{-1}$ in the NP32 and NP50 treatments, respectively), and about half the initial Pi was left at the end of the experiment (Table 2). Considering the increase in $\mathrm{P}$ biomass measured as partP between $\mathrm{T} 0$ and $\mathrm{T} 144$, the decrease in $\mathrm{Pi}$ could explain $85 \pm 26 \%$ of the partP increase in the $\mathrm{N}$ amended treatments. Thus, up to $100 \%$ of the increase in microbial P biomass could be explained by $\mathrm{Pi}$, although variability within replicate treatments was large and suggests that a small fraction of the DOP contributed to the increase in partP. If DOP contributed to the increase in biomass without significant changes in DOP concentration, the DOP must have come from newly produced DOP that was rapidly recycled (Wetz \& Wheeler 2007). As suggested by Björkman et al. (2000), significantly faster turnover times may occur for highly bioavailable DOP compounds (e.g. ATP), and newly produced DOP may be more readily available than older stocks. In our experiment, ATP turnover time decreased from $4.2 \pm 0.2 \mathrm{~d}$ at T0 to $0.26 \pm 0.02 \mathrm{~d}$ at T144 in the Namended treatments. The fast turnover rates of ATP suggest that nucleotides were rapidly degraded and used as a source of $\mathrm{P}$, and single-cell uptake rate data indicate that Synechococcus and bacteria contributed to a similar extent to ATP utilization.

Björkman et al. (2000) showed that in the NPSG, DOP production rates range between approximately 10 and $40 \%$ of the net Pi uptake rate. Considering this range of DOP production in the present study, DOP production would represent only 0.3 to $1.6 \mathrm{nmol}$ DOP $\mathrm{l}^{-1} \mathrm{~d}^{-1}$ in the control but could represent 14.7 to 78 and 16.4 to $89 \mathrm{nmol}$ DOP $\mathrm{l}^{-1} \mathrm{~d}^{-1}$ in the NP32 and NP50 treatments, respectively, which could mask changes in DOP concentrations because of DOP uptake. Growth rates calculated based on changes in average partP concentration (i.e. in P biomass) between T0 and T144 were $0.02,0.20$ and $0.16 \mathrm{~d}^{-1}$ in the control, NP32 and NP50 treatments, respectively, while growth rates based on average specific Pi uptake rate (ratio of Pi uptake rate to partP; Duhamel et al. 2007) at T144 were $0.14 \pm 0.03,2.11 \pm 0.53$ and $2.94 \pm 0.85 \mathrm{~d}^{-1}$ in the control, NP32 and NP50 treatments, respectively. The higher growth rates based on specific Pi uptake rates compared to changes in $\mathrm{P}$ biomass (or cell abundance) suggests that a large fraction of the Pi taken up by the cells was not transformed into biomass and must have been excreted as both Pi and DOP. This is also suggested by the short turnover time of Pi measured at T144 in the $\mathrm{N}$-amended treatments $(4.4 \pm 0.2 \mathrm{~h})$, indicating that the whole Pi stock was used in less than a day while Pi concentration was $>30 \mathrm{nmol} \mathrm{l}^{-1}$, which suggests that net Pi uptake must be a small fraction of gross Pi uptake.

\section{P partitioning between microbial groups in the NPSG}

Using flow cytometry sorting of radiolabeled samples, Björkman et al. (2012) demonstrated that Prochlorococcus and bacteria were equally competitive for Pi but that bacteria contributed to the majority of ATP uptake. Our group-specific measurements in the control samples are in agreement with these findings (Table 3). When $\mathrm{P}$ concentrations are limiting microbial growth, the ability to sequester $\mathrm{P}$ varies among microorganisms (Dyhrman et al. 2007). Since different taxa might rely on different pools of $\mathrm{P}$ and uptake systems, we hypothesized that $\mathrm{P}$ partitioning among microbial groups could be modified as the environment shifts from $\mathrm{N}$ to $\mathrm{P}$ stress. Moreover, Duhamel et al. (2010) demonstrated that Synechococcus was the dominant group with APA when samples from the NPSG were amended with $\mathrm{N}$ to induce $P$ stress and raised the question of whether bacteria and Prochlorococcus were using other sources of $\mathrm{P}$ or uptake mechanisms. Prochlorococcus contribution to Pi and ATP uptake decreased with incubation time because of the decrease in cell abundance (Fig. 2), since their average per-cell uptake rate $\left(\mathrm{dpm} \mathrm{cell}{ }^{-1}\right.$ $\mathrm{h}^{-1}$ ) tends to increase. While there is no evidence of the impact of the surface:volume ratio of incubating bottles on bacterial growth (Hammes et al. 2010), artifacts resulting from bottle confinement have been demonstrated in numerous studies (Gieskes et al. 1979, Marrasé et al. 1992, Calvo-Díaz et al. 2011). In our experience, NPSG seawater incubations longer than $24 \mathrm{~h}$ (i.e. longer than typical incubations used to measure production rates) systematically show that Prochlorococcus cell numbers greatly decrease with incubation time in both nutrient-amended and control samples after $48 \mathrm{~h}$ (McAndrew et al. 2007, Duhamel et al. 2010, Mahaffey et al. 2012). This phenomenon has also been reported in other incubation experiments conducted in other parts of the ocean where seawater was incubated longer than $24 \mathrm{~h}$ (e.g. Jiao et al. 2002, Calvo-Díaz et al. 2011). Hence, time course data obtained for this group, except the initial sample (control at T0), are difficult to interpret, and unfortunately we cannot ascertain their response to induced P stress. Our measurements showed that Synechococcus contribution to both $\mathrm{Pi}$ and ATP uptake in the initial (T0) and incubated control samples was negligible compared to bacteria and Pro- 
chlorococcus (Table 3). However, variations observed in the $\mathrm{N}$-amended treatments suggest that when N limitation is relieved, Synechococcus contribution to Pi and ATP uptake greatly increased to a comparable order of magnitude as bacteria. After $6 \mathrm{~d}$ of incubation, Pi and ATP uptake by the most active Synechococcus population was $>700$ and $>4000$ times larger, respectively, than in the control, suggesting that this microbial group and bacteria could potentially be a key component of the $\mathrm{P}$ cycling when $\mathrm{N}$ limitation is relieved, particularly for DOP utilization (Moutin et al. 2002, Duhamel et al. 2010, Michelou et al. 2011). Previous studies showed that bacteria are superior competitors for Pi compared to phytoplankton (Currie \& Kalff 1984, Drakare 2002), but little is known about phytoplankton-bacterial competitive interactions for DOP (Cotner \& Wetzel 1992, Løvdal et al. 2007, Michelou et al. 2011). Under P-replete conditions, Prochlorococcus and bacteria were the main contributors to Pi uptake and bacteria took up the majority of ATP, while under P stress, Synechococcus contribution to both Pi and ATP uptake was in the same range as bacteria. Interestingly, ATP uptake by bacteria tended to decrease in the $\mathrm{N}$-amended treatments, while their Pi uptake increased, which might be the result of competition with Synechococcus for DOP or shifts in the community structure. These observations suggest that Synechococcus and bacteria could compete for both inorganic and organic P when stressed for P.

Notably, Synechococcus abundances tend to be higher in P-controlled environments such as the Sargasso and Mediterranean Seas (Cotner et al. 1997, Zohary \& Robarts 1998, Wu et al. 2000, Van Wambeke et al. 2002, Thingstad et al. 2005, McLaughlin et al. 2013), while Prochlorococcus abundances tend to be lower than at Stn ALOHA (Campbell \& Vaulot 1993). Synechococcus' capacity to competitively assimilate Pi at low concentrations (Moutin et al. 2002) and its competitive advantage at using DOP (e.g. ATP uptake and APA; Casey et al. 2009, Duhamel et al. 2010, Michelou et al. 2011) could explain its success in low-P environments. Thus, we hypothesize that their abundance might increase in the NPSG as the system is shifting towards P limitation (Karl et al. 2001, Karl 2007).

\section{Response of larger groups to $\mathbf{N}$ amendments}

Although diatom abundances were not investigated in this study, the consumption of $72 \pm 11$ and $82 \pm 15 \%$ of the Si measured at T0 in the NP32 and NP50 treatments, respectively, indicated that this phytoplankton group may have grown in the $\mathrm{N}$-amended treatments. As discussed in Karl \& Letelier (2008), a pulse of inorganic $\mathrm{N}$ into the euphotic zone of subtropical marine habitats selects for rapidly growing, mostly eukaryotic phytoplankton, especially diatoms (McAndrew et al. 2007). Yet, although a large fraction of the Si was consumed, it amounted to only about $0.5 \mu \mathrm{M} \mathrm{Si}$, and the removal of $\mathrm{NO}_{3}{ }^{-}$and $\mathrm{NH}_{4}{ }^{+}$was much greater. Hence, it is most likely that other cells larger than $2 \mu \mathrm{m}$ contributed to processes measured in the $>2 \mu \mathrm{m}$ fraction. In particular, picoalgae showed a pattern of cell abundance comparable to the one observed for ${ }^{14} \mathrm{C}$-PP (Figs. 2D \& 4). Li et al. (2011) showed that although large phytoplankton $(>2 \mu \mathrm{m})$ represent a relatively small fraction of $\mathrm{chl} a$ and ${ }^{14} \mathrm{C}$-PP in the NPSG, their highly variable photophysiological responses suggest that they experience time-variable changes in growth despite constant oligotrophic habitat conditions, which could be one of the reasons for their summer blooms in the NPSG. While the contribution of the $>2 \mu \mathrm{m}$ fraction to ${ }^{14} \mathrm{C}$-PP did not change during our experiment, likely because of co-limitation with another element or vitamin, its contribution to Pi and ATP uptake increased. This result implies that phytoplankton $>2 \mu \mathrm{m}$ have an important effect on the carbon to P stoichiometry of dissolved and particulate pools.

In conclusion, the results of this experiment suggest that microorganisms inhabiting the currently N-controlled NPSG (Van Mooy \& Devol 2008, Duhamel et al. 2011) present mechanisms to quickly respond to P stress (e.g. increase in Pi and ATP uptake rates and $\mathrm{APA}$ ). $\mathrm{N}_{2}$-fixing organisms can form large summer blooms in the NPSG, generally following a diatom bloom hypothesized to be triggered by upwelling of deep water (Wilson 2003, White et al. 2007, Dore et al. 2008, Wilson et al. 2008, Karl et al. 2012, Mahaffey et al. 2012). It has been hypothesized that the diatom bloom quantitatively removes $\mathrm{NO}_{3}{ }^{-}$ and that the residual Pi from the low N:P ratio $(<16: 1)$ in upwelled water stimulates the growth of $\mathrm{N}_{2}$-fixing organisms (McAndrew et al. 2007, Karl \& Letelier 2008, Mahaffey et al. 2012). Results from this experiment imply that the microbial loop could respond quickly to new $\mathrm{N}$ inputs originating from these $\mathrm{N}_{2}$ fixers, strongly modifying the structure of the microbial community as well as the stocks and fluxes of carbon and nutrients. Our results also suggest that the microbial community has the capacity to respond to short-term changes in $\mathrm{P}$ availability and might be able to adapt to scenarios of long-term $\mathrm{P}$ depletion, such as the one predicted for the future NPSG (Karl 
2007, McAndrew et al. 2007), and could potentially maintain ${ }^{14} \mathrm{C}$-PP rates until co-limitation with another essential element or vitamin is reached. The results of this experiment showed that the structure of the microbial community was significantly altered and that resource partitioning among microorganisms was largely modified when the NPSG samples were forced to shift from $\mathrm{N}$ stressed to P stressed. Although this approach needs to be repeated to make robust predictions, these findings have important implications for our understanding of the effects of nutrient status on the structure and functioning of microbial communities.

Acknowledgements. We thank B. Van Mooy, the chief scientist of the KM1013 cruise, and the captain and crew of the RV 'Kilo Moana' for supporting this research. We thank N. Hakoda for her help with sampling and processing the AP samples, M. Segura for $\mathrm{NH}_{4}{ }^{+}$analyses and S. Curless for $\mathrm{NO}_{3}{ }^{-}$analyses. Funds for this work were provided by the Gordon and Betty Moore Foundation's Marine Microbiology Initiative (D.M.K.) and the National Science Foundation (D.M.K., EF0424599; M. J. Church, OCE-0926766).

\section{LITERATURE CITED}

Björkman KM, Karl DM (1994) Bioavailability of inorganic and organic phosphorus compounds to natural assemblages of microorganisms in Hawaiian coastal waters. Mar Ecol Prog Ser 111:265-273

Björkman KM, Karl DM (2001) A novel method for the measurement of dissolved adenosine and guanosine triphosphate in aquatic habitats: applications to marine microbial ecology. J Microbiol Methods 47:159-167

Björkman KM, Karl DM (2005) Presence of dissolved nucleotides in the North Pacific Subtropical Gyre and their role in cycling of dissolved organic phosphorus. Aquat Microb Ecol 39:193-203

Björkman KM, Thomson-Bulldis AL, Karl DM (2000) Phosphorus dynamics in the North Pacific subtropical gyre. Aquat Microb Ecol 22:185-198

Björkman KM, Duhamel S, Karl DM (2012) Microbial group specific uptake kinetics of inorganic phosphate and adenosine-5'-triphosphate (ATP) in the North Pacific Subtropical Gyre. Frontiers Microbiol 3:1-17

> Calvo-Díaz A, Díaz-Pérez L, Suárez LÁ, Morán XAG, Teira E, Marañón E (2011) Decrease in the autotrophic-toheterotrophic biomass ratio of picoplankton in oligotrophic marine waters due to bottle enclosure. Appl Environ Microbiol 77:5739-5746

Campbell L, Vaulot D (1993) Photosynthetic picoplankton community structure in the subtropical North Pacific Ocean near Hawaii (station ALOHA). Deep-Sea Res I 40: 2043-2060

- Casey JR, Lomas MW, Michelou VK, Dyhrman ST, Orchard ED, Ammerman JW, Sylvan JB (2009) Phytoplankton taxon-specific orthophosphate (Pi) and ATP utilization in the western subtropical North Atlantic. Aquat Microb Ecol 58:31-44

Cochlan WP, Harrison PJ (1991) Inhibition of nitrate uptake by ammonium and urea in the eukaryotic picoflagellate
Micromonas pusilla (Butcher) Manton et Parke. J Exp Mar Biol Ecol 153:143-152

Conway HL (1977) Interactions of inorganic nitrogen in the uptake and assimilation by marine phytoplankton. Mar Biol 39:221-232

Cotner JB, Wetzel RG (1992) Uptake of dissolved inorganic and organic phosphorus compounds by phytoplankton and bacterioplankton. Limnol Oceanogr 37:232-243

> Cotner J, Ammerman JW, Peele ER, Bentzen E (1997) Phosphorus-limited bacterioplankton growth in the Sargasso Sea. Aquat Microb Ecol 13:141-149

> Currie DJ, Kalff J (1984) Can bacteria outcompete phytoplankton for phosphorus? A chemostat test. Microb Ecol 10:205-216

$>$ Dore JE, Letelier RM, Church MJ, Lukas R, Karl DM (2008) Summer phytoplankton blooms in the oligotrophic North Pacific Subtropical Gyre: historical perspective and recent observations. Prog Oceanogr 76:2-38

> Dortch Q (1990) The interaction between ammonium and nitrate uptake in phytoplankton. Mar Ecol Prog Ser 61: 183-201

> Drakare S (2002) Competition between picoplanktonic cyanobacteria and heterotrophic bacteria along crossed gradients of glucose and phosphate. Microb Ecol 44: 327-335

> Dugdale RC, Wilkerson FP, Hogue VE, Marchi A (2006) Nutrient controls on new production in the Bodega Bay, California, coastal upwelling plume. Deep-Sea Res II 53: 3049-3062

> Dugdale RC, Wilkerson FP, Hogue VE, Marchi A (2007) The role of ammonium and nitrate in spring bloom development in San Francisco Bay. Estuar Coast Shelf Sci 73: $17-29$

> Duhamel S, Moutin T, Van Wambeke F, Van Mooy B, Rimmelin P, Raimbault P, Claustre H (2007) Growth and specific P-uptake rates of bacterial and phytoplanktonic communities in the Southeast Pacific (BIOSOPE cruise). Biogeosciences 4:941-956

Duhamel S, Dyhrman ST, Karl DM (2010) Alkaline phosphatase activity and regulation in the North Pacific Subtropical Gyre. Limnol Oceanogr 55:1414-1425

> Duhamel S, Björkman KM, Van Wambeke F, Moutin T, Karl DM (2011) Characterization of alkaline phosphatase activity in the North and South Pacific Subtropical Gyres: implications for phosphorus cycling. Limnol Oceanogr $56: 1244-1254$

> Duhamel S, Björkman KM, Karl DM (2012) Light dependence of phosphorus uptake by microorganisms in the subtropical North and South Pacific Ocean. Aquat Microb Ecol 67:225-238

> Dyhrman ST, Haley ST (2006) Phosphorus scavenging in the unicellular marine diazotroph Crocosphaera watsonii. Appl Environ Microbiol 72:1452-1458

Dyhrman ST, Ruttenberg KC (2006) Presence and regulation of alkaline phosphatase activity in eukaryotic phytoplankton from the coastal ocean: implications for dissolved organic phosphorus remineralization. Limnol Oceanogr 51:1381-1390

Dyhrman ST, Ammerman JW, Van Mooy BAS (2007) Microbes and the marine phosphorus cycle. Oceanography 20:110-116

Elser JJ, Bracken MES, Cleland EE, Gruner DS and others (2007) Global analysis of nitrogen and phosphorus limitation of primary producers in freshwater, marine and terrestrial ecosystems. Ecol Lett 10:1135-1142 
Falkowski PG (1997) Evolution of the nitrogen cycle and its influence on the biological sequestration of $\mathrm{CO}_{2}$ in the ocean. Nature 387:272-275

Gieskes WWC, Kraay GW, Baars MA (1979) Current ${ }^{14} \mathrm{C}$ methods for measuring primary production: gross underestimates in oceanic waters. Neth J Sea Res 13:58-78

Hammes F, Vital M, Egli T (2010) A critical evaluation of the volumetric 'bottle effect' on microbial batch growth. Appl Environ Microbiol 76:1278-1281

Hansen HP, Koroleff F (2007) Determination of nutrients. In: Grasshoff K, Kremling K, Ehrhardt M (eds) Methods of seawater analysis. Wiley-VCH Verlag, Weinheim, p $159-228$

Howarth RW (1988) Nutrient limitation of net primary production in marine ecosystems. Annu Rev Ecol Syst 19: 89-110

Jiao NZ, Yang YH, Koshikawa H, Harada S, Watanabe M (2002) Responses of picoplankton to nutrient perturbation in the South China Sea, with special reference to the coast-wards distribution of Prochlorococcus. Acta Bot Sin 44:731-739

Karl DM (2007) The marine phosphorus cycle. In: Hurst CJ (ed) Manual of environmental microbiology. ASM Press, Washington, DC, p 523-539

Karl DM, Björkman K (2002) Dynamics of DOP. In: Hansell DA, Carlson CA (eds) Biogeochemistry of marine dissolved organic matter. Academic Press, San Diego, CA, p 249-366

Karl DM, Holm-Hansen O (1978) Methodology and measurement of adenylate energy charge ratios in environmental samples. Mar Biol 48:185-197

Karl DM, Letelier RM (2008) Nitrogen fixation-enhanced carbon sequestration in low nitrate, low chlorophyll seascapes. Mar Ecol Prog Ser 364:257-268

Karl DM, Tien G (1992) MAGIC: a sensitive and precise method for measuring dissolved phosphorus in aquatic environments. Limnol Oceanogr 37:105-116

Karl DM, Christian JR, Dore JE, Hebel DV, Letelier RM, Tupas LM, Winn CD (1996) Seasonal and interannual variability in primary production and particle flux at Station ALOHA. Deep-Sea Res II 43:539-568

Karl DM, Letelier R, Tupas L, Dore J, Christian J, Hebel D (1997) The role of nitrogen fixation in biogeochemical cycling in the subtropical North Pacific Ocean. Nature 388:533-538

Karl DM, Bidigare RR, Letelier RM (2001) Long-term changes in phytoplankton community structure and productivity in the North Subtropical Gyre: the domain shift hypothesis. Deep-Sea Res II 48:1449-1470

Karl DM, Church MJ, Dore JE, Letelier RM, Mahaffey C (2012) Predictable and efficient carbon sequestration in the North Pacific Ocean supported by symbiotic nitrogen fixation. Proc Natl Acad Sci USA 109:1842-1849

Li B, Karl DM, Letelier RM, Church MJ (2011) Size-dependent photosynthetic variability in the North Pacific Subtropical Gyre. Mar Ecol Prog Ser 440:27-40

Lomas MW, Burke AL, Lomas DA, Bell DW, Shen C, Dyhrman ST, Ammerman JW (2010) Sargasso Sea phosphorus biogeochemistry: an important role for dissolved organic phosphorus (DOP). Biogeosciences 7:695-710

Losada M, Guerrero MG (1979) The photosynthetic reduction of nitrate and its regulation. In: Barber J (ed) Photosynthesis in relation to model systems. Elsevier, Amsterdam, p 365-408

Løvdal T, Tanaka T, Thingstad TF (2007) Algal-bacterial competition for phosphorus from dissolved DNA, ATP, and orthophosphate in a mesocosm experiment. Limnol Oceanogr 52:1407-1419

Mahaffey C, Björkman KM, Karl DM (2012) Phytoplankton response to deep seawater nutrient addition in the North Pacific Subtropical Gyre. Mar Ecol Prog Ser 460:13-34

> Marrasé C, Lim EL, Caron DA (1992) Seasonal and daily changes in bacterivory in a coastal plankton community. Mar Ecol Prog Ser 82:281-289

- McAndrew PM, Björkman KM, Church MJ, Morris PJ, Jachowski N, Williams PJleB, Karl DM (2007) Metabolic response of oligotrophic plankton communities to deep water nutrient enrichment. Mar Ecol Prog Ser 332: 63-75

> McLaughlin K, Sohm JA, Cutter GA, Lomas MW, Paytan A (2013) Phosphorus cycling in the Sargasso Sea: investigation using the oxygen isotopic composition of phosphate, enzyme-labeled fluorescence, and turnover times. Global Biogeochem Cycles 27:375-387

> Menzel DW, Corwin N (1965) The measurement of total phosphorus in seawater based on the liberation of organically bound fractions by persulfate oxidation. Limnol Oceanogr 10:280-282

> Michelou VK, Lomas MW, Kirchman DL (2011) Phosphate and adenosine-5'-triphosphate uptake by cyanobacteria and heterotrophic bacteria in the Sargasso Sea. Limnol Oceanogr 56:323-332

> Middelburg JJ, Nieuwenhuize J (2000) Nitrogen uptake by heterotrophic bacteria and phytoplankton in the nitraterich Thames estuary. Mar Ecol Prog Ser 203:13-21

> Moutin T, Thingstad TF, Van Wambeke F, Marie D, Slawyk G, Raimbault P, Claustre H (2002) Does competition for nanomolar phosphate supply explain the predominance of the cyanobacterium Synechococcus? Limnol Oceanogr 47:1562-1567

Nausch M, Nausch G (2007) Bioavailable dissolved organic phosphorus and phosphorus use by heterotrophic bacteria. Aquat Biol 1:151-160

Orchard E, Webb E, Dyhrman S (2003) Characterization of phosphorus-regulated genes in Trichodesmium spp. Biol Bull 205:230-231

Orrett K, Karl DM (1987) Dissolved organic phosphorus production in surface seawaters. Limnol Oceanogr 32: 383-395

> Pradel E, Boquet PL (1991) Utilization of exogenous glucose1-phosphate as a source of carbon or phosphate by Escherichia coli K12: respective roles of acid glucose-1phosphatase, hexose-phosphate permease, phosphoglucomutase and alkaline phosphatase. Res Microbiol 142: $37-45$

Redfield AC (1934) On the proportions of organic derivations in seawater and their relation to the composition of plankton. In: Daniel RJ (ed) James Johnson Memorial Volume. Liverpool University Press, p 177-192

> Ruttenberg KC, Dyhrman ST (2012) Dissolved organic phosphorus production during simulated phytoplankton blooms in a coastal upwelling system. Front Microbiol 3: 274

Siuda W, Chróst RJ (2001) Utilization of selected dissolved organic phosphorus compounds by bacteria in lake water under non-limiting orthophosphate conditions. Pol J Environ Stud 10:475-483

Sohm JA, Capone DG (2010) Zonal differences in phosphorus pools, turnover and deficiency across the tropical North Atlantic Ocean. Global Biogeochem Cycles 24: 


\section{GB2008, doi:10.1029/2008GB003414}

Talarmin A, Van Wambeke F, Duhamel S, Catala P, Moutin T, Lebaron P (2011) Improved methodology to measure taxon-specific phosphate uptake in live and unfiltered samples. Limnol Oceanogr Methods 9:443-453

Tanaka T, Rassoulzadegan F, Thingstad TF (2004) Orthophosphate uptake by heterotrophic bacteria, cyanobacteria, and autotrophic nanoflagellates in Villefranche Bay, northwestern Mediterranean: vertical, seasonal, and short-term variations of the competitive relationship for phosphorus. Limnol Oceanogr 49:1063-1072

Tanaka T, Henriksen P, Lignell R, Olli K, Seppala J, Tamminen T, Thingstad TF (2006) Specific affinity for phosphate uptake and specific alkaline phosphatase activity as diagnostic tools for detecting phosphorus-limited phytoplankton and bacteria. Estuaries Coast 29:1-16

Thingstad TF, Krom MD, Mantoura RFC, Flaten GAF and others (2005) Nature of phosphorus limitation in the ultraoligotrophic eastern Mediterranean. Science 309: 1068-1071

Treseder K, Balser T, Bradford M, Brodie E and others (2011) Integrating microbial ecology into ecosystem models: challenges and priorities. Biogeochemistry 109:7-18

Tyrrell $\mathrm{T}$ (1999) The relative influences of nitrogen and phosphorus on oceanic primary production. Nature 400: 525-531

> Van Mooy B, Devol AH (2008) Assessing nutrient limitation of Prochlorococcus in the North Pacific subtropical gyre by using an RNA capture method. Limnol Oceanogr 53: 78-88

Van Mooy BAS, Fredricks HF, Pedler BE, Dyhrman ST and others (2009) Phytoplankton in the ocean use nonphosphorus lipids in response to phosphorus scarcity. Nature 458:69-72

Editorial responsibility: Ronald Kiene, Mobile, Alabama, USA
Van Wambeke F, Christaki U, Giannakourou A, Moutin T, Souvemerzoglou K (2002) Longitudinal and vertical trends of bacterial limitation by phosphorus and carbon in the Mediterranean Sea. Microb Ecol 43:119-133

- Watkins-Brandt KS, Letelier RM, Spitz YH, Church MJ, Böttjer D, White AE (2011) Addition of inorganic or organic phosphorus enhances nitrogen and carbon fixation in the oligotrophic North Pacific. Mar Ecol Prog Ser 432:17-29

> Wetz MS, Wheeler PA (2007) Release of dissolved organic matter by coastal diatoms. Limnol Oceanogr 52:798-807

White AE, Spitz YH, Letelier RM (2007) What factors are driving summer phytoplankton blooms in the North Pacific Subtropical Gyre? J Geophys Res 112:C12006, doi:10.1029/2007JC004129

Wilson C (2003) Late summer chlorophyll blooms in the oligotrophic North Pacific Subtropical Gyre. Geophys Res Lett 30:1942, doi:10.1029/2003GL017770

Wilson C, Villareal TA, Maximenko N, Bograd SJ, Montoya JP, Schoenbaechler CA (2008) Biological and physical forcings of late summer chlorophyll blooms at $30^{\circ} \mathrm{N}$ in the oligotrophic Pacific. J Mar Syst 69:164-176

> Wu J, Sunda W, Boyle EA, Karl DM (2000) Phosphate depletion in the western North Atlantic Ocean. Science 289: 759-762

Zehr JP, Ward BB (2002) Nitrogen cycling in the ocean: new perspectives on processes and paradigms. Appl Environ Microbiol 68:1015-1024

> Zohary T, Robarts RD (1998) Experimental study of microbial P limitation in the eastern Mediterranean. Limnol Oceanogr 43:387-395

Zubkov MV, Mary I, Malcolm E, Woodward S and others (2007) Microbial control of phosphate in the nutrientdepleted North Atlantic subtropical gyre. Environ Microbiol 9:2079-2089

Submitted: July 1, 2013; Accepted: February 6, 2014 Proofs received from author(s): April 19, 2014 